\title{
小型圧縮コイルばねの温間へたりに関する共同研究報告
}

\author{
圧縮コイルばねの温間へたりに関する研究委員会
}

\section{Report on High-Temperature Spring Set of Compact Compression Coil Springs}

\author{
Research Committee on High-Temperature Spring Set of Compression Coil Springs
}

\begin{abstract}
This committee aimed to provide technical information (commentary) that can predict high-temperature spring set (residual shearing strain " $\gamma$ value") when designing and manufacturing compact coil springs for engine valve. The committee was divided into "Literature WG (Working Group)" and "Test WG", and Literature WG gathered and organized technical literatures related to " $\gamma$ value" at higher temperature. Test WG used test springs of which the wire diameter $\phi 1.0,4.0 \mathrm{~mm}$ of 3 steel types (SWP - A, SWOSC - V, SUS 304 - WPB), including with processing or without processing(non) of shot peening and setting. Test temperature was set from 100 to $450{ }^{\circ} \mathrm{C}$, clamping time was set from 24 to $312 \mathrm{~h}$, and the hightemperature spring set (calculated to " $\gamma$ value") was measured after clamping test at higher temperature. Various data of " $\gamma$ value" obtained with less variance, and the influence of loaded stress, temperature and time on " $\gamma$ value" with reasonable tendency for each test element. We confirmed that the obtained data generally agreed with various data in past technical literatures. So, we think that the obtained data will be able to provide useful database. However, in this activity, we cannot reconsider using the obtained data about highly practical calculation formula to express the difference at the temperature range (low temperature: around $200{ }^{\circ} \mathrm{C}$, high temperature: around $350{ }^{\circ} \mathrm{C}$ ). In the future, it is necessary to verify the high-temperature spring set mechanism at higher temperature and re-examination of highly practical calculation formulas.
\end{abstract}

Key Words: High-temperature spring set Residual shearing strain "value" Compact coil spring Valve spring Clamping test

\section{1 活動概要}

\section{1. 緒言}

圧縮コイルばねの「へたり」は，弁ばね用などの小型コイ ルばねにおいてもサスペンション用の比較的大きなコイル ばねにおいても，歴史的にばね製品使用上の重要特性とし て注目され，古くから「へたり」に関する試験研究が多く行 われ，日本ばね学会(前身のばね技術研究会を含む)ではへ たりに関する研究委員会をくり返し組織して積極的に研究 され，多くの貴重なデー夕，情報が提供されてきた。その 中で，弁ばねのへたりは，高温のエンジン内で使用される ことから「 $\left(200^{\circ} \mathrm{C}\right.$ 前後の) 温間へたり」が重要特性となり，か
つ使用材料も炭素鋼，ばね鋼，ステンレス鋼など多岐にわ たるため過去から幅広く研究されてきた。

今回の「圧縮コイルばねの温間へたりに関する研究委員 会(温間へたり委員会)」は，日本ばね工業会の委嘱により， 2014年9月から「ばねメーカーが小型コイルばねを設計・製 作する時に，“温間へたり量”をある程度予測できるような 技術情報(解説)を作成すること」を目指して活動した。

まず全体委員会にて過去の同主旨の研究委員会活動報告 などの文献を参考にしながら温間へたり測定試験計画を立 案した後，試験WGと文献WGに分かれて各種調查試験準 備を進めた。文献WGでは，温間へたりに関連するキーワー 
ド群を設定し, ばね論文集はじめ広範囲に文献情報を収集 整理した。試験WGでは，(一般社団法人)日本ばね工業会 発行の「(JSMA SD010)圧縮コイルばね耐熱性試験方法」に 準拠し，3鋼種(標準的なSWP-A及びSWOSC-V，へたり情 報ニーズが大きいSUS304-WPB)の小型コイルばね（線径 $\phi$ $1.0,4.0 \mathrm{~mm})$ を供試ばねとして, ショットピーニング(以下 ではSP) 及びセッチング(以下ではSE)の有無も含め, 鋼種 によるが締付試験の温度を $100 \sim 450^{\circ} \mathrm{C}$ ，時間を $24 \sim 312 \mathrm{~h}$ と して負荷応力を変化させた温間締付試験を行って「へたり (残留せん断ひずみ“ $\gamma$ 值”) に換算. 以下では $\gamma$ 值」を測定 し, 関連特性調査を実施した。 なお, 評価対象は静的へた りながら, 動的へたりとの比較も検討できるように, ばね 諸元は(2015年) ばね論文集で報告された「圧縮コイルばね の疲労限度線図に関する共同研究報告」1)のばね仕様を参照 した。

活動期間は2014年9月～2018年1月で，以下に活動内容を 報告する。

\section{2 研究委員会構成}

研究委員会の委員は下記の通りで, 途中で一部交代は

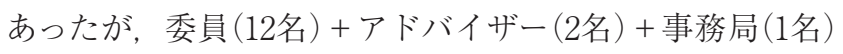
の計15名で文献WGと試験WGに分かれて活動した。 委員長罢一博 (高周波熱錬(株) 副委員長 (試験WG長) 岡本貴幸 (中央発條(侏)) 副委員長 (文献WG長) 岡田文徳 (住友電工(株))

委員 (試験WG) (荻原寛之(住友電工(株) 2017/3) ) 島 恵吾 $($ 三菱製鋼(株) $)$ 中野淳一 (日本発条(株) 細田洋平 $($ 日鉄住金SGW(株) 福田尚悟 (中央発條株) 横井隆樹 (株)東郷製作所)

（文献WG）北原洋一(株)アドバネクス) 酒井信吾(株パイオラックス) （濱田＼cjkstart剛～2016/4） 津山貴昭(後藤工業(株)) 山先祥太(新日鐵住金ステンレス(株)) アドバイザー 丹下 彰(日本発条(侏) 井上信彦 (日本ばね工業会) 事務局 礒貝一秀 (日本ばね学会) (押田 守〜2016/6)

\section{2. 文献調査結果 (文献WG)}

\section{1 文献の抽出方法と主要文献}

全体委員会にて，今回の温間へたり研究委員会の対象鋼 種をSWP-A, SWOSC-V, SUS304-WPBと決定し, 文献WG では，まず1952年から2015年までのばね論文集掲載の論文, 解説, 研究委員会報告など計728文献を各委員が分担調査 して, 温間へたり関連情報が得られそうな文献を絞り込み, 各種キーワード(たとえば, 鋼種, 線径, 線材特性, コイル ばね諸元, 一次焼鈍条件, 窒化処理の有無, SPの有無, 二
次燒鈍条件, SEの有無, 及びへたり測定のための締付試験 条件(方法, 温度, 時間, 負荷応力など))を読み出して一覧 表に整理した。次にその中から, Table 2-1に示す主要キー

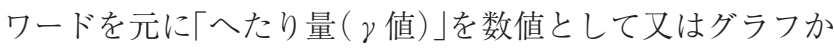
ら読み取れる值として入手可能で，かつへたり試験条件な どの具体的な記述がある主要文献を対象として18文献に絞 り込んだ 19)。他に，線径は10.5mmながら「ばね論文集 第30号 (1985)共同研究：熱間成形コイルばねのへたり試験 法に関する研究/神原広司委員長」20), 又, へたり挙動に関 する解析を進めた「ばね論文集 第59号(2014)共同研究:圧 縮コイルばねのへたりに関する研究委員会報告/新谷紀雄 委員長」21) も参考にした.

Table 2-2〜2-4に最終的に抽出した18文献のばね論文集 の号(発行年), タイトル, 対象鋼種, 結言(抜粋)を示す。

Table 2-1 Keywords to extract the relevant literatures.

\begin{tabular}{|l|l|}
\hline \multicolumn{2}{|l|}{ Survey target literatures: “Transaction of JSSE"(1952 2015) 728 items } \\
\hline Items & Contents \\
\hline Steels & SWP-A, SWOSC-V, SUS304-WPB \\
\hline Spring shape & Compression coil spring (out of wire data only) \\
\hline $\begin{array}{l}\text { Residual shearing strain } \\
\text { “ } \gamma \text { value" }\end{array}$ & Actual data, readable data in the graph \\
\hline $\begin{array}{l}\text { Related parameter of } \gamma \\
\text { (in Clamping test) }\end{array}$ & Temperature, Time, Load(stress) \\
\hline \begin{tabular}{l} 
Others \\
\multicolumn{2}{|l}{}
\end{tabular} & $\begin{array}{l}\text { Micro-structure, Hardness, Residual stress } \\
\text { Specification of spring } \\
\text { Heat-treatment condition (stress relief annealing) } \\
\text { Setting (with processing/condition or without (non)) } \\
\text { Shot peening (with processing/condition or non) }\end{array}$ \\
\hline
\end{tabular}

Table 2-2 Literatures mainly extracted. (1/3)

\begin{tabular}{|c|c|l|l|l|}
\hline $\begin{array}{c}\text { Index } \\
\text { No. }\end{array}$ & $\begin{array}{c}\text { Paper No. } \\
\text { (year) }\end{array}$ & \multicolumn{1}{|c|}{ Title } & Steel type & \multicolumn{1}{|c|}{ Conclusion (overview) } \\
\hline (1) & $\begin{array}{c}\text { No.9 } \\
\text { (1963) }\end{array}$ & $\begin{array}{l}\text { High temperature static loading } \\
\text { test of cold formed coil spring } \\
\text { (Report 1) } \\
\text { ※Author 's translation. Because of } \\
\text { no English title }\end{array}$ & $\begin{array}{l}\text { SWP-A } \\
\text { SWOC-V } \\
\text { SWOC-VV }\end{array}$ & $\begin{array}{l}\text { SWOC-VV is one of the most excellent } \\
\text { steel for higher spring set resistance } \\
\text { (lower height reduction). }\end{array}$ \\
\hline (2) & $\begin{array}{l}\text { No.10 } \\
(1964)\end{array}$ & $\begin{array}{l}\text { On the heat resisting and Fatigue } \\
\text { Properties of Oil Tempered Si-Cr } \\
\text { Spring Steel Wire }\end{array}$ & $\begin{array}{l}\text { SWOSC-V } \\
\text { SWOCV-V }\end{array}$ & $\begin{array}{l}\text { SWOSC-V is superior to SWOCV-V in } \\
\text { tensile property, spring set, fatigue } \\
\text { property as heat resistant spring. }\end{array}$ \\
\hline (3) & $\begin{array}{l}\text { No.10 } \\
(1964)\end{array}$ & $\begin{array}{l}\text { On the Spring Properties of Oil } \\
\text { Tempered Cr-Si Spring Steel Wire }\end{array}$ & $\begin{array}{l}\text { SWOSC-V } \\
\text { SWOCV-V }\end{array}$ & $\begin{array}{l}\text { SWOSC-V is superior to SWOCV-V in } \\
\text { heat resistance and has excellent spring } \\
\text { set resistance. }\end{array}$ \\
\hline (4) & $\begin{array}{l}\text { No.11 } \\
(1966)\end{array}$ & $\begin{array}{l}\text { Report of the Co-operated } \\
\text { Experiment on Stainless Steel } \\
\text { Spring Wires }\end{array}$ & SUS27,others & $\begin{array}{l}\text { In the clamping test, the influence of } \\
\text { temperature is greater than clamping } \\
\text { stress and time. }\end{array}$ \\
\hline (5) & $\begin{array}{l}\text { No.12 } \\
(1967)\end{array}$ & $\begin{array}{l}\text { The Influence of Elevated } \\
\text { Temperature on the Set of Coil } \\
\text { Springs made of Oil Tempered Si- } \\
\text { Cr,Cr-V Spring Steel Wire }\end{array}$ & $\begin{array}{l}\text { SWOSC-V } \\
\text { SWOCV-V }\end{array}$ & $\begin{array}{l}\text { Spring set appears at relatively early } \\
\text { stage of clamping test, and the amount of } \\
\text { spring set varies depending on the manu- } \\
\text { facturing process and steel type. }\end{array}$ \\
\hline (6) & $\begin{array}{l}\text { No.12 } \\
\text { (1967) } \\
\text { ※No.1213 } \\
\text { (bothin 1967) }\end{array}$ & $\begin{array}{l}\text { Improvement of Spring made of Si- } \\
\text { Cr Steel Oil Tempered Wire by } \\
\text { means of Low Temperature } \\
\text { Cyaniding }\end{array}$ & SWOSC-V & $\begin{array}{l}\text { To reduce high-temperature spring set in } \\
\text { both static, dynamic loading, low- } \\
\text { temperature Cyaniding (carbonitriding) } \\
\text { are effective. }\end{array}$ \\
\hline
\end{tabular}


Table 2-3 Literatures mainly extracted. (2/3)

\begin{tabular}{|c|c|l|l|l|}
\hline $\begin{array}{c}\text { Index } \\
\text { No. }\end{array}$ & $\begin{array}{c}\text { Paper No. } \\
\text { (year) }\end{array}$ & \multicolumn{1}{|c|}{ Title } & \multicolumn{1}{|c|}{ Steel type } & \multicolumn{1}{c|}{ Conclusion (overview) } \\
\hline (7) & $\begin{array}{l}\text { No.13 } \\
(1967)\end{array}$ & $\begin{array}{l}\text { Study on the Endurance Properties } \\
\text { of Valve Springs for Automobile }\end{array}$ & $\begin{array}{l}\text { SWP-V } \\
\text { SWO-V } \\
\text { SWOSC-V }\end{array}$ & $\begin{array}{l}\text { The deformation limit does not have } \\
\text { fixed relationship with the high } \\
\text { temperature elastic limit, and it is } \\
\text { greatly affected by the steel type. }\end{array}$ \\
\hline (8) & $\begin{array}{l}\text { No.14 } \\
(1969)\end{array}$ & $\begin{array}{l}\text { Study on the Stainless Steel Wire } \\
\text { for Spring }\end{array}$ & SUS27WH-C & $\begin{array}{l}\text { The static and dynamic heat resistance } \\
\text { characteristics of SUS 27WH-C are } \\
\text { equal to or slightly better than that of } \\
\text { SWO - SC. }\end{array}$ \\
\hline (9) & $\begin{array}{l}\text { No.17 } \\
(1972)\end{array}$ & $\begin{array}{l}\text { Study on the Stainless Steel Wire } \\
\text { for Spring (part 2) }\end{array}$ & $\begin{array}{l}\text { SUS27WH-B } \\
\text { SUS27WH-C }\end{array}$ & $\begin{array}{l}\text { The residual shearing strain of } \\
\text { SUS27WH are affected by the } \\
\text { difference in wire drawing process. The } \\
\text { transverse elastic modulus slightly } \\
\text { increases after the clamping test. }\end{array}$ \\
\hline (10) & $\begin{array}{l}\text { No.20 } \\
(1975)\end{array}$ & $\begin{array}{l}\text { Stainless Steel Spring Wire } \\
\text { Resistance to pitting Corrosion (15t } \\
\text { Reports) }\end{array}$ & $\begin{array}{l}\text { SUS316 } \\
\text { SUS304 } \\
\text { SUS304+Mo }\end{array}$ & $\begin{array}{l}\text { When Mo is added to SUS 304, the } \\
\text { spring set resistance is improved. }\end{array}$ \\
\hline (11) & $\begin{array}{l}\text { No.25 } \\
(1980)\end{array}$ & $\begin{array}{l}\text { Study on the Fatigue Strength of } \\
\text { High Strength Wires for Spring }\end{array}$ & $\begin{array}{l}\text { SWC } \\
\text { SWP-A } \\
\text { SWO-V,others }\end{array}$ & $\begin{array}{l}\text { The spring set resistance of high- } \\
\text { strength steel wire of carbon steel type } \\
\text { can not be expected to be effective even } \\
\text { if it is made high strength. }\end{array}$ \\
\hline (12) & $\begin{array}{l}\text { No.28 } \\
(1983)\end{array}$ & $\begin{array}{l}\text { Study of the High Strength } \\
\text { Stainless Steel Wires for Spring }\end{array}$ & $\begin{array}{l}\text { SUS304-WPB } \\
\text { SUS631-WPC }\end{array}$ & $\begin{array}{l}\text { The spring set resistance: } \\
\text { austenitic type subzero processing } \\
\text { > precipitation hardening type. }\end{array}$ \\
\hline
\end{tabular}

Table 2-4 Literatures mainly extracted. (3/3)

\begin{tabular}{|c|c|c|c|c|}
\hline $\begin{array}{l}\text { Index } \\
\text { No }\end{array}$ & $\begin{array}{c}\text { Paper No. } \\
\text { (year) }\end{array}$ & Title & Steel type & Conclusion (overview) \\
\hline (13) & $\begin{array}{l}\text { No.29 } \\
(1984)\end{array}$ & $\begin{array}{l}\text { Improved High Tensile Strength } \\
\text { Stainless Steel }\end{array}$ & $\begin{array}{l}\text { SUS304-WPB } \\
\text { SWP-B }\end{array}$ & $\begin{array}{l}\text { Residual shearing strain of spring at high } \\
\text { temperature clearly differs among steel } \\
\text { types. }\end{array}$ \\
\hline (14) & $\begin{array}{l}\text { No.32 } \\
(1987)\end{array}$ & $\begin{array}{l}\text { Effect of Spring Index on Set at } \\
\text { High Temperature of Coil Spring }\end{array}$ & $\begin{array}{l}\text { SWP-A } \\
\text { SWOSC-V } \\
\text { SUS304-WPB }\end{array}$ & $\begin{array}{l}\text { The influence of the spring index and the } \\
\text { pitch angle (within } 8.5^{\circ} \text { to } 12^{\circ} \text { ) on } \\
\text { high-temperature spring set is small. }\end{array}$ \\
\hline (15) & $\begin{array}{l}\text { No.34 } \\
(1989)\end{array}$ & $\begin{array}{l}\text { Long-Term Elevated Temperature } \\
\text { Setting Properties of Oil Tempered } \\
\text { Cr-Si Steel Wire (SWOSC-V) and } \\
\text { Stainless Steel Wire (SUS304- } \\
\text { WPB)Springs }\end{array}$ & $\begin{array}{l}\text { SWOSC-V } \\
\text { SUS304-WPB }\end{array}$ & $\begin{array}{l}\text { By the analysis, the temperature } \\
\text { dependency of the coefficients was } \\
\text { different from the temperature region } \\
\text { (the boundary temperature / about 200 } \\
250^{\circ} \text { C). Future task to consider. }\end{array}$ \\
\hline (16) & $\begin{array}{l}\text { No.40 } \\
(1995)\end{array}$ & $\begin{array}{l}\text { Studies on High-Strength Oil- } \\
\text { Tempered Chromium-Silicon Alloy } \\
\text { Steel Wire for Valve Springs }\end{array}$ & $\begin{array}{l}\text { SWOSC-V } \\
\text { High strength } \\
\text { SWOSC-V }\end{array}$ & $\begin{array}{l}\text { When the spring wire becomes stronger, } \\
\text { the spring set resistance descends. } \\
\text { (some conditions are excluded) }\end{array}$ \\
\hline (11) & $\begin{array}{l}\text { No.46 } \\
(2001)\end{array}$ & $\begin{array}{l}\text { Governing Factors in the Fatigue } \\
\text { Endurance of Austenitic Stainless } \\
\text { Steel Wire }\end{array}$ & $\begin{array}{l}\text { SUS302 } \\
\text { SUS304 }\end{array}$ & $\begin{array}{l}\text { The spring set at } 300,400^{\circ} \mathrm{C} \text { is not so } \\
\text { good to get higher tensile strength of } \\
\text { wire. (the reason is unknown) }\end{array}$ \\
\hline (BB) & $\begin{array}{l}\text { No.58 } \\
\text { (2013) }\end{array}$ & $\begin{array}{l}\text { The Annealing Conditions of Coil } \\
\text { Spring }\end{array}$ & $\begin{array}{l}\text { SWP-B } \\
\text { SWOSC-V } \\
\text { SUS304-WPB }\end{array}$ & $\begin{array}{l}\text { SWOSC-V: } 360 \text { to } 420^{\circ} \mathrm{C} \\
\text { SUS } 304-W P B: 350 \text { to } 450^{\circ} \mathrm{C} \text {. } \\
\text { Annealing at these temperature range } \\
\text { reduce the spring set. }\end{array}$ \\
\hline
\end{tabular}

\section{2 抽出文献の解析と考察}

\subsection{1 抽出文献 (18 種類) の精読調査}

$\gamma$ 值の記載がある抽出文献の各鋼種について, 締付試験 での温度と負荷応力を読み取り, 当該文献番号も記入して 試験条件分布表を作成した. Table 2-5にSWOSC-V (SP無, SE有)の例を示す，試験WGでは文献WGが作成したこのよ うな条件分布を参考にして，へたり測定試験でのコイルば ねのSP, SEの有無, 締付試験での温度, 負荷応力, 時間な どの試験条件を設定した。

$\gamma$ 值が記載されている抽出文献情報からSPとSEの有無を 読み出した結果, Table 2-6に示すように, SPとSEの有無 については，様々な組合わせのデータがあることが判明し たが, 今回の文献調査では, 各鋼種とも, SP無, SE有のコ イルばねを主体にした。
Table 2-5 Test condition distribution table, temperature and clamping stress in the high-temperature spring set test of extracted literatures.

(SWOSC-V / SP non, with SE, number such as (15) is the reference literature number in Table 2-2 to $2-4$ )

\begin{tabular}{|c|c|c|c|c|c|c|c|c|}
\hline \multicolumn{9}{|c|}{$\lceil S W O S C-V 」[S P(X /$ non:without processing $), S E(O$ with processing $)]$} \\
\hline $\begin{array}{c}\text { Clamping } \\
\text { Stress } \\
\tau_{0}(\mathrm{MPa})\end{array}$ & $20^{\circ} \mathrm{C}$ & $100^{\circ} \mathrm{C}$ & $150^{\circ} \mathrm{C}$ & $200^{\circ} \mathrm{C}$ & $250^{\circ} \mathrm{C}$ & $300^{\circ} \mathrm{C}$ & $350^{\circ} \mathrm{C}$ & $400^{\circ} \mathrm{C}$ \\
\hline \multicolumn{9}{|l|}{900} \\
\hline 800 & & (14) & (14) & (14)(15) & & (14) & & \\
\hline 700 & & (14)(15) & (14)(15) & (14)(15) & & (14) & & \\
\hline 600 & & (14)(15) & (14) (15) & (14)(15) & (15) & (14)(15) & (15) & (15) \\
\hline 500 & & (7)(14)(15) & (7)(14)(15) & $\begin{array}{l}\frac{5(7)}{(14)(15)} \\
\end{array}$ & (5)(7)(15) & (5)(14)(15) & (15) & (15) \\
\hline 400 & & (7)(15) & (7)(15) & (5) (7)(15) & (5)(7)(15) & (5)(15) & (15) & (15) \\
\hline 300 & & (7) & (7) & (7) & (7)(15) & (15) & (15) & (15) \\
\hline 200 & & & & & & & & \\
\hline
\end{tabular}

Table 2-6 Combination of with processing and without processing (non) of SP and SE of coil spring in extracted literatures.

[Number of data indicating residual shear strain " $\gamma$ value"]

(SP: Shot Peening, SE: Setting)

\begin{tabular}{|c|c|c|c|c|}
\hline \multirow{2}{*}{ Steel type } & \multicolumn{2}{|c|}{$(\mathrm{X}) \mathrm{SP}$} & \multicolumn{2}{c|}{$(\mathrm{O}) \mathrm{SP}$} \\
\cline { 2 - 5 } & $(\mathrm{X}) \mathrm{SE}$ & $(\mathrm{O}) \mathrm{SE}$ & $(\mathrm{X}) \mathrm{SE}$ & $(\mathrm{O}) \mathrm{SE}$ \\
\hline SWP-A & 40 & 36 & 0 & 72 \\
\hline SWOSC-V & 281 & 658 & 0 & 448 \\
\hline SUS304-WPB & 71 & 1656 & 3 & 12 \\
\hline & $\begin{array}{l}\text { O: with processing } \\
\text { X/non: without processing }\end{array}$ \\
\hline
\end{tabular}

\subsection{2 各鋼種の $\gamma$ 值の整理・解析 \\ 2.2.2.1 SWP-A鋼の $\gamma$ 值}

SWP-Aについては, 締付試験での温度 $250^{\circ} \mathrm{C}, \mathrm{SP}$ 無, SE 無での負荷応力及び時間と $\gamma$ 実測值との関係を読み取って 図にプロットした結果，Fig. 2-1に示すように， $\gamma$ 值は締付 初期に急速に増加し, 時間が長くなると増加率は低下し, 負荷応力が大きくなると絶対值が大きくなるという納得性 のある傾向が確認できた。 


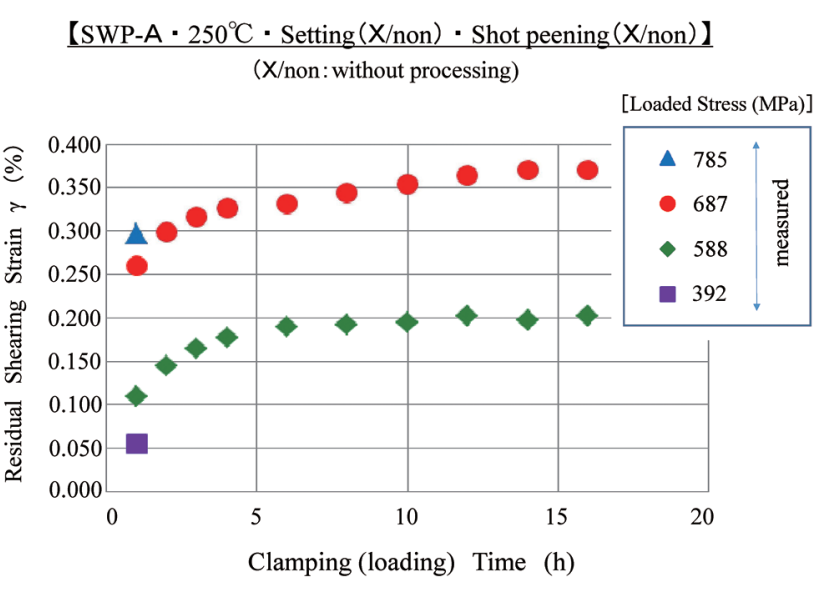

Fig. 2-1 Relationship between time, clamping stress and residual shearing strain " $\gamma$ value" in hightemperature spring set test at $250{ }^{\circ} \mathrm{C}$. [SWP-A] (literature (1))

\subsubsection{2 $\gamma$ 值の構成（計算）式}

SWOSC-VとSUS304-WPBについては, SWP-Aと同様 に締付試験での温度, SP及びSEの有無をべースに, 負 荷応力及び時間と $\gamma$ 值との関係を図にプロットし, さらに 「Table 2-4の文献15). ばね論文集 第34号(1989)：共同研 究“SWOSC-V及びSUS304-WPB耐熱ばねの長時間へたり特 性/田中千秋委員長」16)で報告されたTable 2-7の(1) 式に示 す “ $\gamma$ 值の構成式(予測計算式)”を用いて $\gamma$ 值を計算して文 献から読み取った実測值と比較した。

Table 2-7 Calculation formula of $\gamma$ value (composition formula) in the past literature (15).

\begin{tabular}{l|c|c|c|c|c|c|c}
\hline \multirow{2}{*}{ Steel type } & \multirow{2}{*}{$\begin{array}{c}\text { Temperature } \\
\text { (C) }\end{array}$} & \multicolumn{5}{|c}{$\gamma$ (Residual shearing strain/calculated \%) } \\
\cline { 3 - 8 } & 0 & $\mathrm{~m}$ & $\mathrm{a}$ & $\mathrm{b}$ & $\mathrm{c}$ & $\begin{array}{l}\text { correlation } \\
\text { coefficient }\end{array}$ \\
\hline \multirow{3}{*}{ SWOSC-V } & $100 \sim 200$ & $8.344 \times 10^{-4}$ & $1.039 \times 10^{-1}$ & $1.124 \times 10^{-1}$ & $-6.036 \times 10^{2}$ & $-1.769 \times 10^{1}$ & 0.957 \\
\cline { 2 - 8 } & $250 \sim 400$ & $1.152 \times 10^{6}$ & $1.531 \times 10^{-1}$ & $-1.131 \times 10^{-1}$ & $-1.092 \times 10^{4}$ & $9.012 \times 10^{1}$ & 0.979 \\
\hline \multirow{3}{*}{ SUS304-WPB } & $150 \sim 250$ & $7.165 \times 10^{-5}$ & $7.980 \times 10^{-2}$ & $1.283 \times 10^{-1}$ & $1.165 \times 10^{3}$ & $3.137 \times 10^{1}$ & 0.915 \\
\cline { 2 - 8 } & $300 \sim 400$ & $1.198 \times 10^{5}$ & $1.280 \times 10^{-1}$ & $-1.223 \times 10^{-1}$ & $-1.007 \times 10^{4}$ & $1.024 \times 10^{2}$ & 0.981 \\
\hline
\end{tabular}

$$
\gamma=D t^{m} \exp \left(a \tau_{0}\right) \exp \left[\left(b+c \tau_{0}\right) /(T+273)\right] \cdots(1)
$$

ここで温度域が違う場合に予測計算式内の各係数の值が 異なるが, これは, 文献15)では, 多くのデー夕を元に統計 的手法を用いた直線回帰式からの帰納法によりTable 2-7に 示す構成式(1) を求め, 各定数 $(D, m, a, b, c)$ は各温度 での $\gamma$ 実測值を入れて計算すると回帰直線の傾きが2つの 温度域 (SWOSC-Vでは100 200 ${ }^{\circ} \mathrm{C}$ と250 400 C, SUS304WPBでは150〜 250 $\mathrm{C}$ と300〜 400 C) で異なり，それぞれの 直線の相関係数が高くなる定数を算出して提示したためで ある。

予測計算式が温度域によって二つに分かれることに関し ては，「ばね論文集 第59号(2014)：圧縮コイルばねのへ たりに関する研究委員会報告/新谷紀雄委員長 ${ }^{211}$ において,
長時間 (主に3000h) 試験でのへたり量の増加傾向(直線近似 した場合の線の傾き) が100〜 $200^{\circ} \mathrm{C}$ と350〜 400 $\mathrm{C}$ では異な ることから，両温度域でのへたりのメカニズム(いわゆるク リープ現象と類似挙動と推定)に違いがあると推察し, 国 内外の種々の文献を参考にメカニズムを検討した結果，材 料学的な検証は行われていないが, 低温域では固溶 $\mathrm{C}+\mathrm{N}$ によるコットレル効果が, 高温域では固溶 $\mathrm{C}+\mathrm{N}$ と置換型固 溶元素 $(\mathrm{Si}, \mathrm{Cr}, \mathrm{Mn})$ との複合雲囲気によるIS (InterstitialSubstitutional Interaction) 効果が支配的と推定している. これは $\gamma$ 值を低温域でも高温域でもより高精度に推定する ために貴重な見解である.

\subsubsection{SWOSC-V鋼の $\gamma$ 值}

文献からSP無, SE有の締付試験での時間と負荷応力 と $\gamma$ 值の実測值を読み取り, 計算值を加えてプロットし, Fig. 2-2に $200^{\circ} \mathrm{C}$ の図(文献(5)(7)(15))を，Fig. 2-3に300 Cの図 (文献(5)(15))を示す.

いずれの温度の場合も, SWP-Aと同様に $\gamma$ 值は締付試 験初期に急速に増加し, 時間が長くなると増加率は低下 し，負荷応力が大きくなると絶対值は大きくなるが，負荷 応力 $686 \mathrm{MPa}$ での值は, SWOSC-V $\left(200^{\circ} \mathrm{C} / 300 \mathrm{~h}\right)$ がSWP-A $\left(250^{\circ} \mathrm{C} / 16 \mathrm{~h}\right)$ の0.3倍以下とかなり小さいことが示されて いる.

$200^{\circ} \mathrm{C}, 300^{\circ} \mathrm{C}$ もに $\gamma$ 計算值と $\gamma$ 実測值の差は, 締付試 験初期には $\gamma$ 值の絶対值が小さいこともあり, プロット上 はわかりにくいが，負荷応力が大きくなり，時間が長くな ると大きくなる傾向が見られ, $200^{\circ} \mathrm{C}$ では負荷応力 $785 \mathrm{MPa}$,

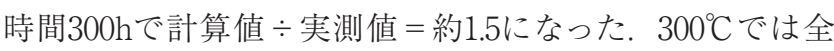
体に $\gamma$ 実測值が大きくなり，686MPa，300hでの $300^{\circ} \mathrm{C} の$

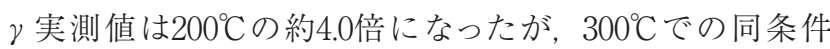

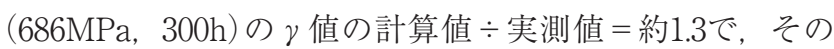
差は比較的少なかった。

【SWOSC-V $\cdot 200^{\circ} \mathrm{C} \cdot$ Setting $(O) \cdot$ Shot peening $(\mathrm{X} /$ non $) 】$ ( $\mathrm{O}$ : with processing $\mathrm{X} /$ non: without processing)

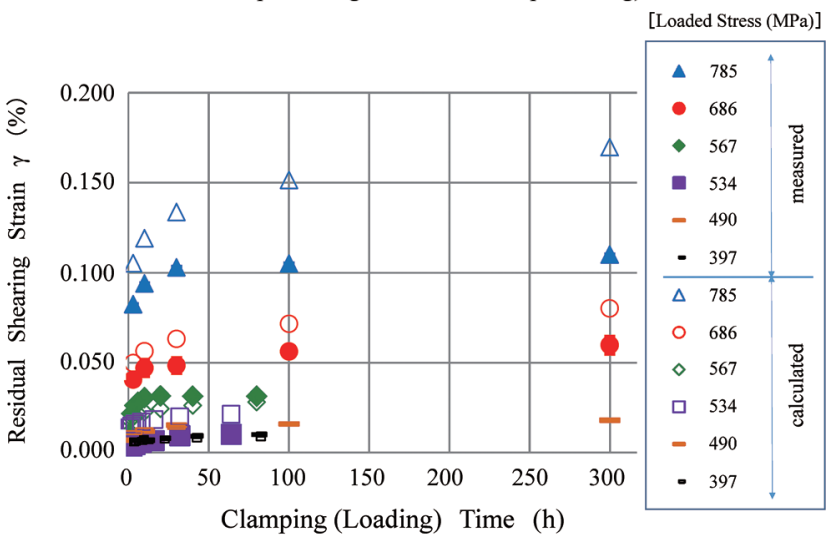

Fig. 2-2 Relation between time, clamping stress and $\gamma$ value in high-temperature spring set test at $200{ }^{\circ} \mathrm{C}$. (calculated and measured values) $[$ SWOSC-V] (5) (7)(15) 
【SWOSC-V $\cdot 300^{\circ} \mathrm{C} \cdot \operatorname{Setting}(\mathrm{O}) \cdot \operatorname{Shot}$ peening $(\mathrm{X} / \mathrm{non}) 】$

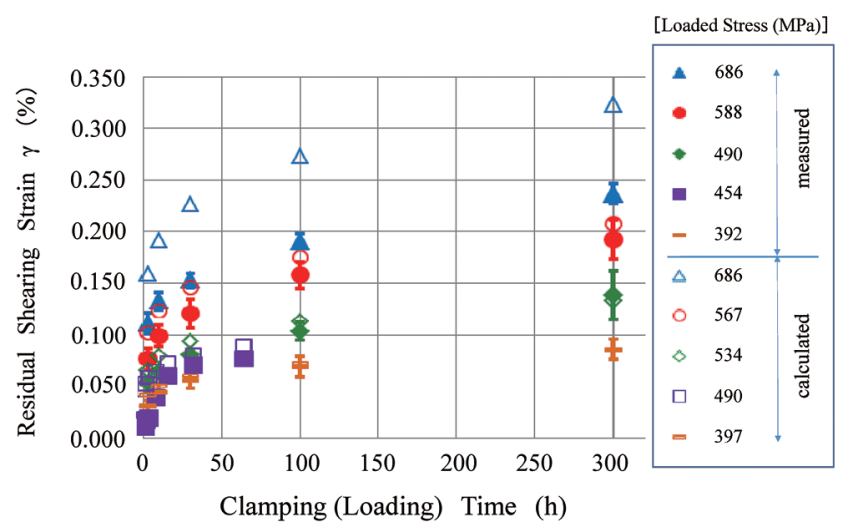

Fig. 2-3 Relation between time, clamping stress and $\gamma$ value in high-temperature spring set test at $300{ }^{\circ} \mathrm{C}$. (calculated and measured values) [SWOSC-V] (5)(15)

\subsubsection{SUS304-WPB鋼の $y$ 値}

同様に文献からSP無，SE有の締付試験での時間と負荷応 力と $\gamma$ 值の実測值を読み取り, Fig. 2-4に200 Cでの実測值 のみの図(文献8)(15) を, Fig. 2-5に計算值を加えた図を示し,

Fig. 2-6に300 Cの図(文献9)を示す.

いずれの温度でも，実測值は，SWP-A，SWOSC-Vと同 様に締付試験初期に急速に増加し, 時間が長くなると増加 率は低下し, 負荷応力が大きくなると絶対值が大きくなる 傾向を示し, 負荷応力約600MPaでの值は, SUS304-WPB $\left(300^{\circ} \mathrm{C} / 80 \mathrm{~h}\right)$ がSWOSC-V $\left(300^{\circ} \mathrm{C} / 300 \mathrm{~h}\right)$ の0.7倍程度と少し 小さかった。

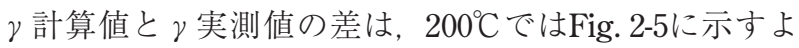
うに $\gamma$ 計算值が異常值となり $\gamma$ 実測值とは大きく乘離した。 $300^{\circ} \mathrm{C}$ ではFig. 2-6に示すようにFig. 2-3に示したSWOSC-Vの $300^{\circ} \mathrm{C}$ での傾向と同様に, 各負荷応力で $\gamma$ 計算值がやや大き く, 負荷が小さくなると, $\gamma$ 計算值 $\div \gamma$ 実測值 $=$ 約 1.0 とほ ぼ同等になった。

$\underline{\text { [SUS304WPB } \cdot 200^{\circ} \mathrm{C} \cdot \operatorname{Setting}(\mathrm{O}) \cdot \text { Shot peening }(X / \text { non }) \text { 】 }}$

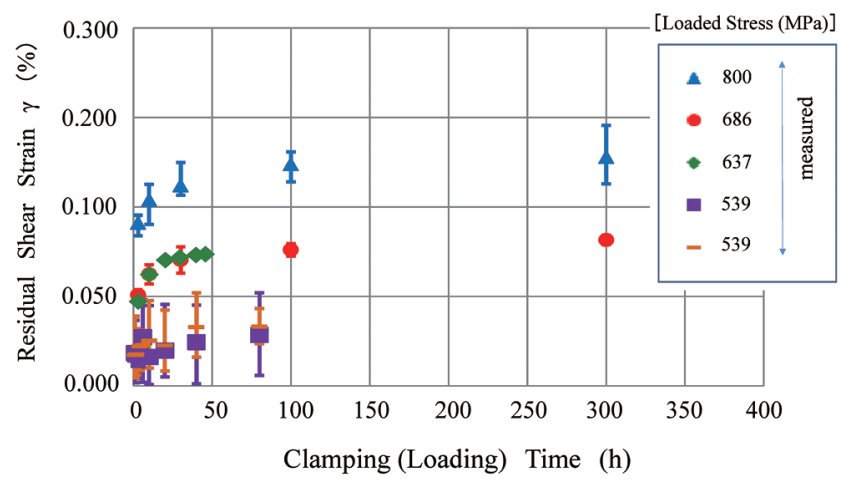

Fig. 2-4 Relation between time, clamping stress and $\gamma$ value in high-temperature spring set test at $200^{\circ} \mathrm{C}$. (measured values) [SUS304-WPB] (8)(15)
【SUS304WPB $\cdot 200^{\circ} \mathrm{C} \cdot \operatorname{Setting}(\mathrm{O}) \cdot \operatorname{Shot}$ peening $(\mathrm{X} / \mathrm{non}) 】$

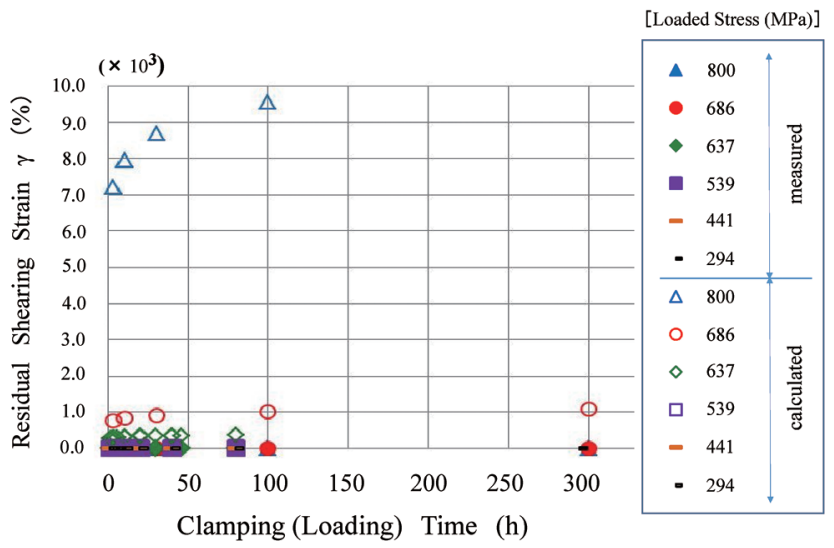

Fig. 2-5 Relation between time, clamping stress and $\gamma$ value in high-temperature spring set test at $200{ }^{\circ} \mathrm{C}$. (calculated and measured values) [SUS304-WPB] (8)(15)

\section{【SUS304WPB $\cdot 300^{\circ} \mathrm{C} \cdot \operatorname{Setting}(O) \cdot$ Shot peening $(X /$ non $) 】$}

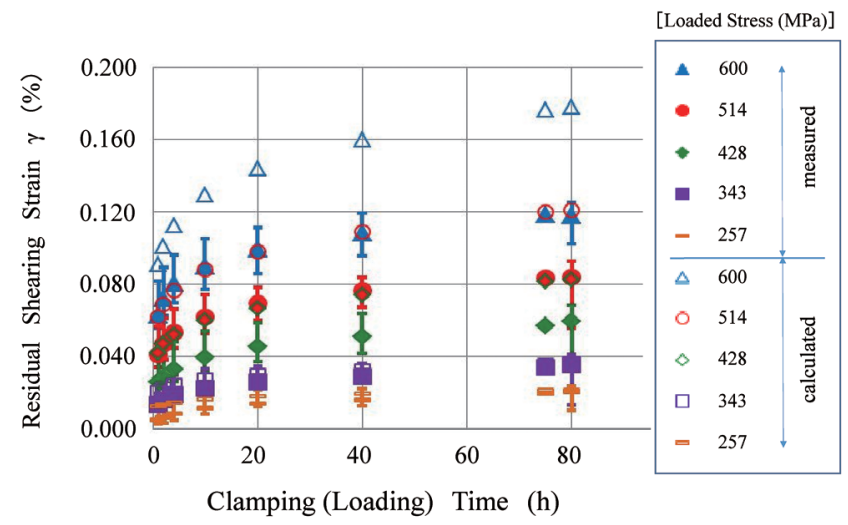

Fig. 2-6 Relation between time, clamping and $\gamma$ value in high-temperature spring set test at $300{ }^{\circ} \mathrm{C}$.

(calculated and measured values) [SUS304-WPB] (9)

Fig. 2-2〜2-6の原文献から読み取れた各種定性定量情 報, $\gamma$ 計算值と $\gamma$ 実測值の差をよりわかりやすく明示する ために，各文献のコイルばね製造条件，締付試験での最 長時間に抢ける各種条件と $\gamma$ 值との関係を整理し, $\gamma$ 值の 計算值と $\gamma$ 実測值の比 $(\gamma$ 計算值 $/ \gamma$ 実測值)を算出した.

Table 2-8にSWP-A及びSWOSC-Vの一覧表を, Table 2-9 にSUS304-WPBの一覧表を示す.

両一覧表から読み取れる傾向は，Fig. 2-2〜2-6に関するコ メントの通りである.

（参考文献欄に, 参考のため, 和文表記の表を示す) 
Table 2-8 List of conditions of high-temperature spring set test, such as the with processing or without processing (non) of SP and SE, temperature, clamping stress, time (longest time), and $\gamma$ value (calculated / measured value). [SWP-A (measured only) and SWOSC-V]

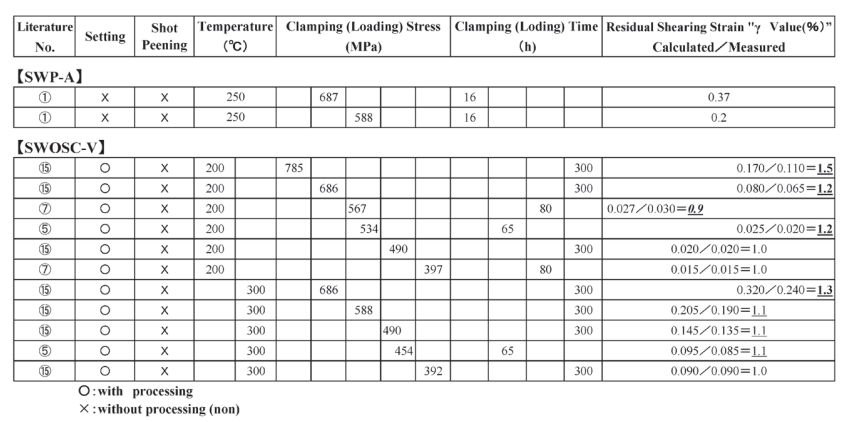

Table 2-9 List of conditions of high-temperature spring set test, such as the with processing or without processing (non) of SP and SE, temperature, clamping stress, time (longest time), and $\gamma$ value. (calculated / measured value) [SUS304WPB]

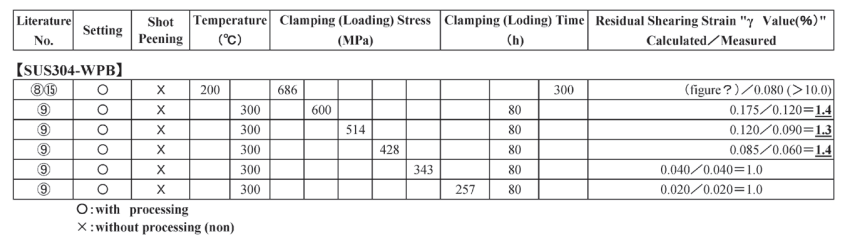

\section{$2.3 \gamma$ 值構成（計算）式から算出した $\gamma$ 值傾向予測}

Fig. 2-7にSWOSC-Vで負荷応力500MPaの場合の締付 試験での温度, 時間と $\gamma$ 計算值の関係を示し, Fig. 2-8に SUS304-WPBで負荷応力500MPaの場合の締付試験での300 $\sim 400^{\circ} \mathrm{C}$ 間の温度，時間と $\gamma$ 計算值の関係を示す。両図にお いて，例えば1000hは実試験外ではあるが計算で外挿が可 能となる。なお, SUS304-WPBの $200^{\circ} \mathrm{C}$ 前後の $\gamma$ 計算值は $\gamma$ 実測值と大きく乘離し温度依存性も逆傾向(高温になると $\gamma$ 計算值が減少)になるため, この温度域でのオーステナイト 系ステンレス鋼特有の現象かどうかを含めて, $\gamma$ 值構成式 の精度検証が今後の課題となる。

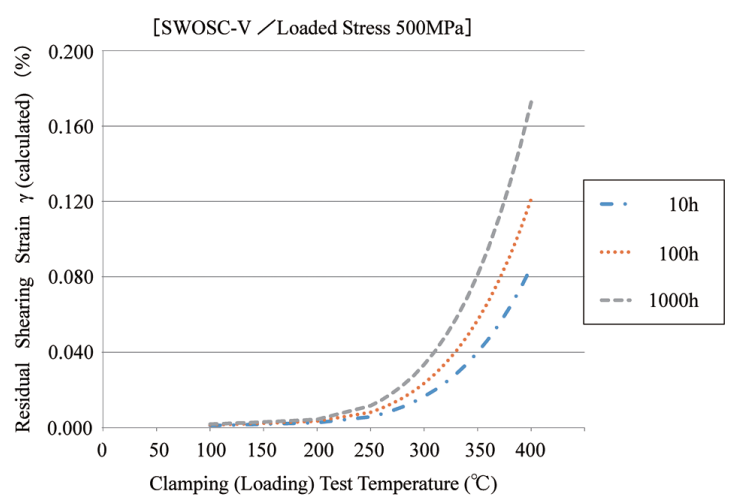

Fig. 2-7 Relation between $\gamma$ calculated value and temperature, clamping time in spring set test. [SWOSC-V]

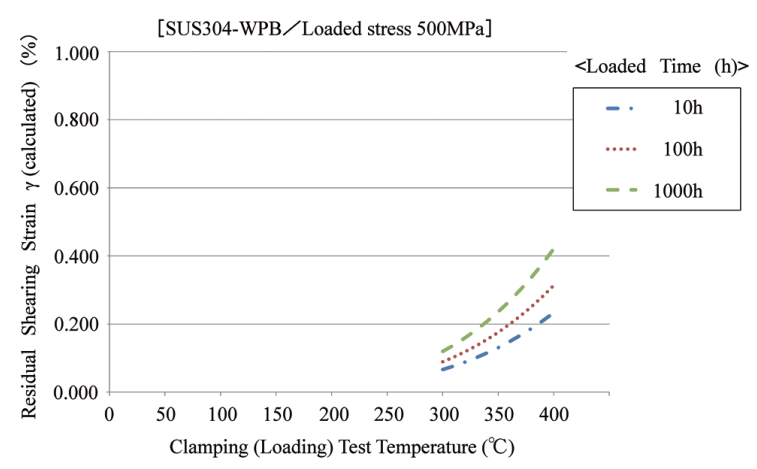

Fig. 2-8 Relation between $\gamma$ calculated value and temperature, clamping time in spring set test. [SUS304-WPB]

\section{4 試験WGとの連携}

文献WGで収集整備した文献情報や一覧表化などの整理 結果から得られた情報は，全体委員会などの機会に試験 WGにも展開し，試験WGでの締付試験条件設定や関連特性 調查の参考にした.

\section{5 関連規格及び海外文献規格情報}

規格としては，前述した(一般社団法人) 日本ばね工業会 発行の「(JSMA SD010)圧縮コイルばね耐熱性試験方法」を 参照した。 又，海外文献規格についても，米国のSMI発行 の「SPRINGS」誌における「温間へたりに関する記事」を調査 した (2010年冬号〜2017年冬号まで計30冊)が，参考になる 情報が無いことを確認した。

\section{6 文献WGのまとめ}

(1) $\gamma$ 実測值の傾向の法則性 : 同じ文献毎に整理を行うと, 一定の相関はあるが，複数の文献での $\gamma$ 実測值を混合さ せるとばらつきが大きくなり, 法則性は崩れることがわ かった。

(2)計算值との整合性 : SWOSC-Vの温度 $200^{\circ} \mathrm{C}$, 締付応力が $500 \mathrm{MPa}$ 以下の条件時に $\gamma$ 実測值と $\gamma$ 計算值との乘離は 最大でも 1.5 倍程度で比較的少なかった。

(3)たた， SUS304-WPBの温度 $200^{\circ} \mathrm{C} の \gamma$ 計算值はどの負荷 応力の場合も絶対值が大きくなり， $\gamma$ 実測值との乘離も 非常に大きくなった.

(4) SP有無の影響: SP有の文献データが少なかったため, 有無の影響について比較はできなかった。

(5) $\gamma$ 值構成式の適用性 : Fig. 2-7及びFig. 2-8に示したよう に,コイルばね製造条件, 締付試験(実使用環境)の諸情 報が入手できれば $\gamma$ 值構成式 (1) により $\gamma$ 值を計算して $\gamma$ 值予測図が作成出来ることから， $\gamma$ 值構成式 (1)の精 度を，たとえば後述の試験WGの実測值や統計的計算手 法の改善により高めることが出来れば, 本委員会の目標 とした「ばねメーカーが小型コイルばねを設計・製作す る時に, “温間へたり量 $(\gamma$ 值 $)$ をある程度予測できるよ うな技術情報(解説)を作成する」に繋がる可能性がある と考えられる。 


\section{3. 温間へたり試験結果（試験WG）}

本委員会でへたり試験を行うにあたり, 線種(鋼種)の選 定や試験方法については, 過去の文献やJSMAの標準をも とに，以下の通りで行うこととした

\section{1 供試ばね線}

Table 3-1 に今回使用したばね線についてまとめた，線種 は，よく用いられるSWP-A，SWOSC-Vと，より高温で用い られることの多いSUS304-WPBを選択し, 線径は $\phi 1.0 \mathrm{~mm}$ と $\phi 4.0 \mathrm{~mm}$ の種類を選択した。この線径については，本委員 会に先立って行われた「圧縮コイルばねの疲労限度線図の改 訂調査研究委員会」1で用いられたものと同様である.

なお，今回のばね線は日鉄住金SGワイヤー(侏)，住友電工 スチールワイヤー(侏)，鈴木住電ステンレス(侏の 3 社に提供い ただいた

Table 3-2に各線種の化学成分と機械的特性をまとめた. いずれもJIS規格内に入っており問題ないことを確認できた

Fig. 3-1にばね線の組織写真を, Fig. 3-2に硬さ測定結果 を示した

Table 3-1 Summaries about wire.

\begin{tabular}{|c|c|c|}
\hline Grade & $\begin{array}{c}\text { Diameter } \\
\varphi(\mathrm{mm})\end{array}$ & Wire provided company \\
\hline SWP-A & 1.0 & NIPPON STEEL \& SUMIKIN SG WIRE CO., ITD. \\
\hline \multirow{2}{*}{ SWOSC-V } & $\frac{4.0}{1.0}$ & \multirow{2}{*}{ Sumitomo (SEI) Steel Wire Corp. } \\
\hline & 4.0 & \\
\hline SUS304-WPB & $\begin{array}{l}1.0 \\
4.0\end{array}$ & SUZUKI-SUMIDEN STRINLESS STEEL WIRE CO., LTD. \\
\hline
\end{tabular}

Table 3-2 Mechanical properties and chemical compositions of steel wires.

\begin{tabular}{|c|c|c|c|c|c|c|c|c|c|c|}
\hline \multirow{2}{*}{ Grade } & \multirow{2}{*}{$\begin{array}{l}\text { Diameter } \\
\text { O(mm) }\end{array}$} & \multirow{2}{*}{\begin{tabular}{|c|} 
Tensile strength \\
$(\mathrm{MPa})$
\end{tabular}} & \multicolumn{8}{|c|}{ Chemical compositions (massil) } \\
\hline & & & c & $\mathrm{Si}$ & Mn & $P$ & $S$ & $\mathrm{Cu}$ & $\mathrm{N}$ & $\mathrm{Cr}$ \\
\hline SWP-AQ 1.0 & 0.995 & 2139 & 0.81 & 0.17 & 0.50 & 0.012 & 0.004 & 0.01 & - & - \\
\hline & & & 0.82 & 0.17 & 0.49 & 0.012 & 0.004 & 0.01 & - & - \\
\hline SWOSC-V & & & 0.58 & 1.44 & 0.68 & 0.000 & 0.007 & 0.01 & - & 0.68 \\
\hline SWOSC-V & & & 0.57 & 1.44 & 0.69 & 0.007 & 0.006 & 0.01 & - & 0.68 \\
\hline SUS3O4-WPB Q 1.0 & 0.9 & & 0.070 & 0.41 & 1.26 & 0.032 & 0.004 & - & 8.48 & 18.08 \\
\hline SUS3O4-YPB $\odot 4.0$ & 3.999 & 1955 & 0.070 & 0.47 & 1.22 & 0.031 & 0.002 & - & 8.46 & 18.01 \\
\hline
\end{tabular}

\section{2 供試ばね}

\subsection{1ばね諸元および製造条件}

Table 3-3に試験に用いたばね諸元を示す。ショットピー

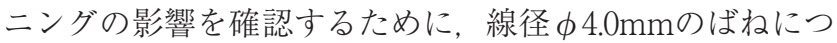
いては, ショットピーニングを施した。

Fig. 3-3にばねの製造工程を，Table 3-4, Table 3-5には 低温焼なまし条件とショットピーニング条件を示す.ばねの 製造については, 線径 $\phi 1.0 \mathrm{~mm}$ は日本発条(侏), 線径 $\phi 4.0 \mathrm{~mm}$ は(侏)東郷製作所に協力いただき，ショットピーニング処理 については,新東工業(侏に協力いただいた。

セッチング応力は, 過去の試験条件を参考に, 次の值で 行ったこの值は修正係数を考慮しない值である.

SWP-A, SWOSC-V : 1000MPa

SUS304-WPB : 850MPa

また,セッチングは3回行った.

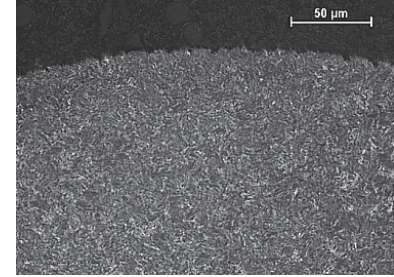

(a) SWP-A $\phi 1.0 \mathrm{~mm}$

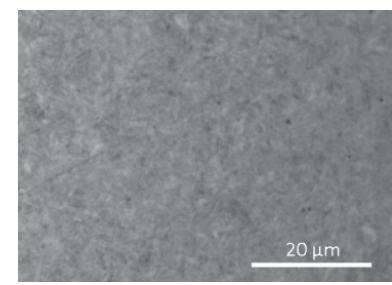

(c) SWOSC-V $\phi 1.0 \mathrm{~mm}$

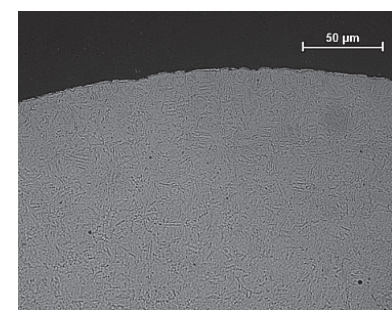

(e) SUS304-WPB $\phi 1.0 \mathrm{~mm}$

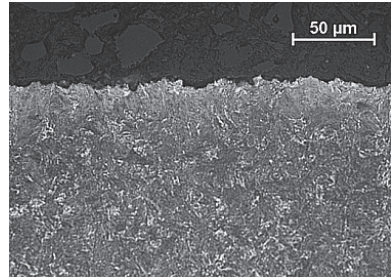

(b) SWP-A $\phi 4.0 \mathrm{~mm}$

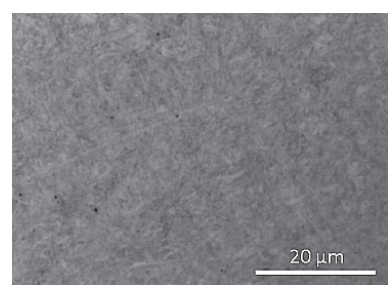

(d) SWOSC-V $\phi 4.0 \mathrm{~mm}$

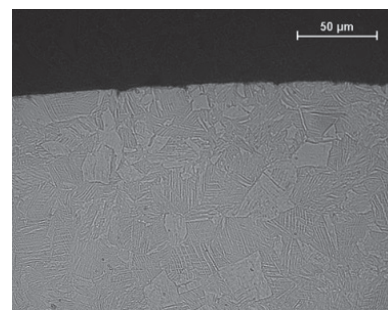

(f) SUS304-WPB $\phi 4.0 \mathrm{~mm}$
Fig. 3-1 Optical microstructure of wire cross-sections.

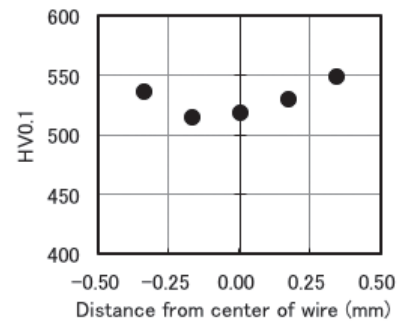

(a) SWP-A $\phi 1.0 \mathrm{~mm}$

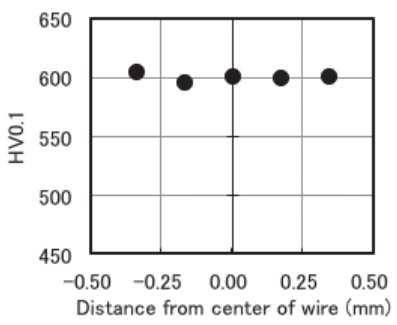

(c) SWOSC-V $\phi 1.0 \mathrm{~mm}$

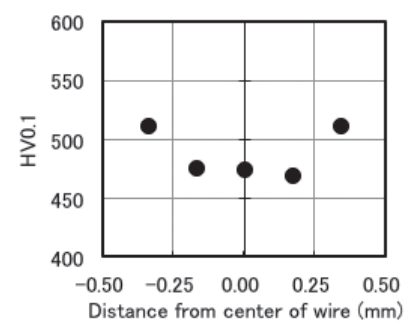

(e) SUS304-WPB $\phi 1.0 \mathrm{~mm}$

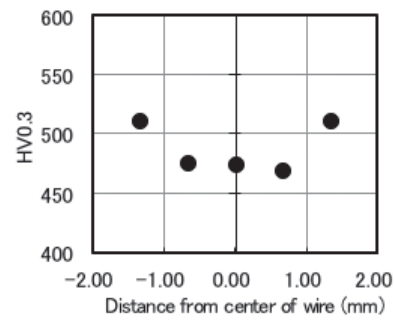

(b) SWP-A $\phi 4.0 \mathrm{~mm}$

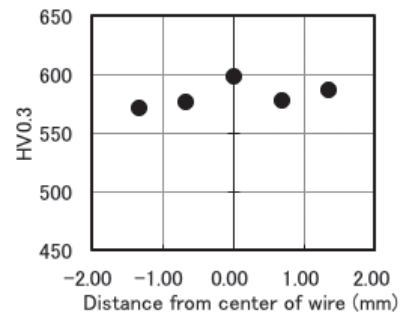

(d) SWOSC-V $\phi 4.0 \mathrm{~mm}$

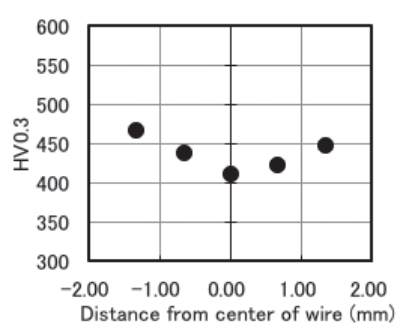

(f) SUS304-WPB $\phi 4.0 \mathrm{~mm}$
Fig. 3-2 Hardness distributions of specimen wires. 
Table 3-3 Dimensions of designed specimen springs.

\begin{tabular}{|c|c|c|c|c|}
\hline Materials & \multicolumn{2}{|c|}{ SWP-A, SWOSC-V } & \multicolumn{2}{c|}{ SUS304-WPB } \\
\hline Wire diameter $(\mathrm{mm})$ & $\phi 1.0$ & $\phi 4.0$ & $\phi 1.0$ & $\phi 4.0$ \\
\hline Average of diameter $(\mathrm{mm})$ & 6.0 & 24.0 & 6.0 & 24.0 \\
\hline Number of total coils & 9.5 & 6.0 & 10.5 & 7.0 \\
\hline Number of active coils & 7.5 & 4.0 & 8.5 & 5.0 \\
\hline Free height (mm) & 25.0 & 52.0 & 25.0 & 60.0 \\
\hline End shape & \multicolumn{5}{|c|}{ Closed end and Grinding } \\
\hline Shot peening & Non & Treated & Non & Treated \\
\hline
\end{tabular}

\section{Coiling $\Rightarrow$ Annealing $\Rightarrow$ Grinding}

\section{$\rightarrow$ (1) Setting \\ (2) Shot Peening $\Rightarrow$ Annealing $\Rightarrow$ Setting}

Fig. 3-3 Manufacturing Process of coil springs.

Table 3-4 Conditions of annealing.

\begin{tabular}{|c|c|c|c|c|}
\hline & & $\phi 1.0 \mathrm{~mm}$ & & \\
\hline Specimer & & Annealing & Annealing & Annealing \\
\hline SWP-A & & $350^{\circ} \mathrm{C}-10 \mathrm{~min}$. & $350^{\circ} \mathrm{C}-20 \mathrm{~min}$. & \\
\hline SWOSC-V & norn. & $420^{\circ} \mathrm{C}-10 \mathrm{~min}$. & $420^{\circ} \mathrm{C}-20 \mathrm{~min}$. & \\
\hline SUS304-WPB & & $400^{\circ} \mathrm{C}-30 \mathrm{~min}$. & $400^{\circ} \mathrm{C}-30 \mathrm{~min}$. & \\
\hline SWP-A & & & $350^{\circ} \mathrm{C}-20 \mathrm{~min}$. & $230^{\circ} \mathrm{C}-15 \mathrm{~min}$ \\
\hline SWOSC-V & SP & & $420^{\circ} \mathrm{C}-20 \mathrm{~min}$. & $230^{\circ} \mathrm{C}-15 \mathrm{~min}$ \\
\hline SUS304-WPB & & & $400^{\circ} \mathrm{C}-30 \mathrm{~min}$. & $230^{\circ} \mathrm{C}-15 \mathrm{~min}$ \\
\hline
\end{tabular}

Table 3-5 Conditions of Shot peening (SP).

\begin{tabular}{|c|c|}
\hline Peening media & $0.6 \mathrm{~mm} \mathrm{CCW}$ \\
\hline Shot velocity & $78 \mathrm{~m} / \mathrm{s}$ \\
\hline Projectile amount rate & $130 \mathrm{~kg} / \mathrm{min}$. \\
\hline Coverage & $200 \%$ \\
\hline Arc-height & $0.350 \mathrm{mmA}$ \\
\hline
\end{tabular}

\section{2 .2 ばね特性}

Fig. 3-4 ( (a)〜 (f)) に供試ばねの線間すきま線図を示す. 巻き形状に異常は見られない.

Fig. 3-5( (a)〜 (f)) に荷重-たわみ線図を示す.いずれのば ねも線形特性が得られており,試験をする上で問題ないこと を確認した.また,ショットピーニングを施しても,ばね特性に 変化がないことも確認した。

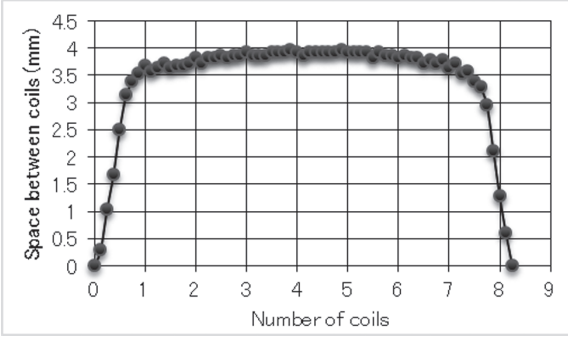

(a) SWP-A $\phi 1.0 \mathrm{~mm}$

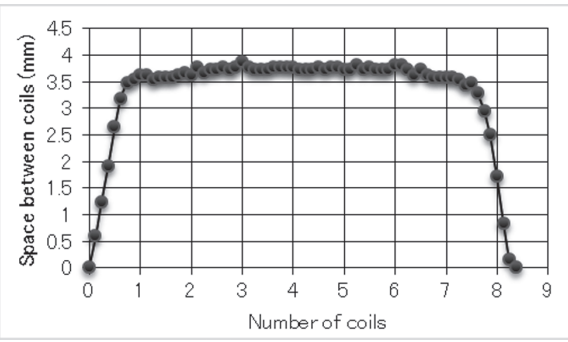

(b) SWOSC-V $\phi 1.0 \mathrm{~mm}$

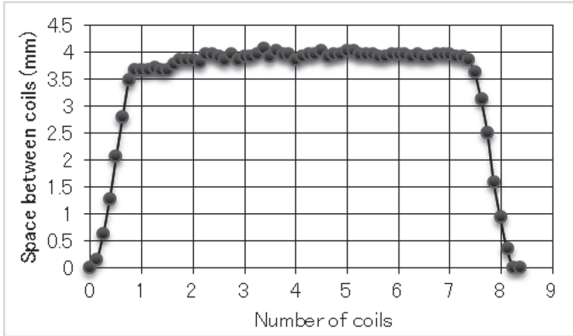

(c) SUS304-WPB $\phi 1.0 \mathrm{~mm}$

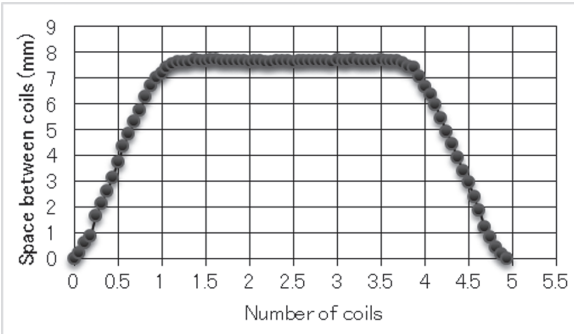

(d) SWP-A $\phi 4.0 \mathrm{~mm}$

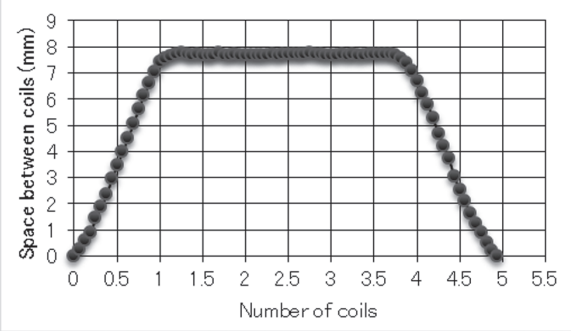

(e) SWOSC-V $\phi 4.0 \mathrm{~mm}$

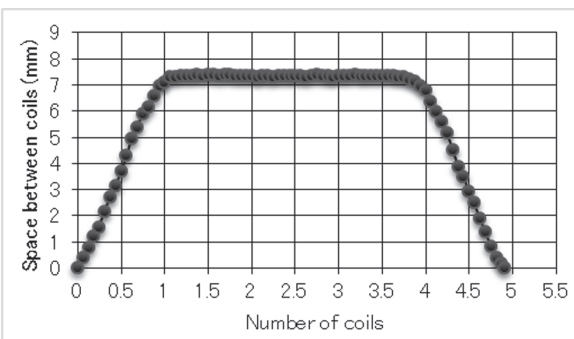

(f) SUS304-WPB $\phi 4.0 \mathrm{~mm}$

Fig. 3-4 Space between coils-diagrams of specimens. 


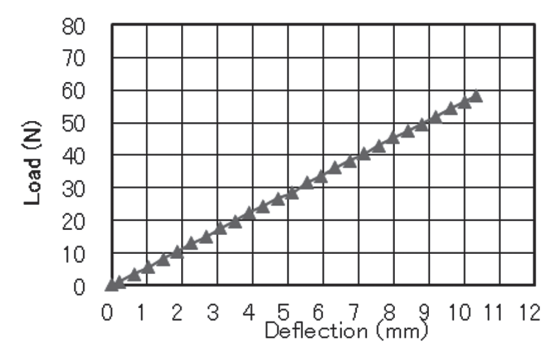

(a) SWP-AP-A $\phi 1.0 \mathrm{~mm}$.

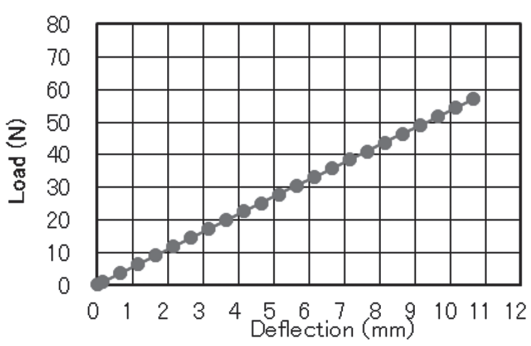

(b) SWOSC-V $\phi 1.0 \mathrm{~mm}$.

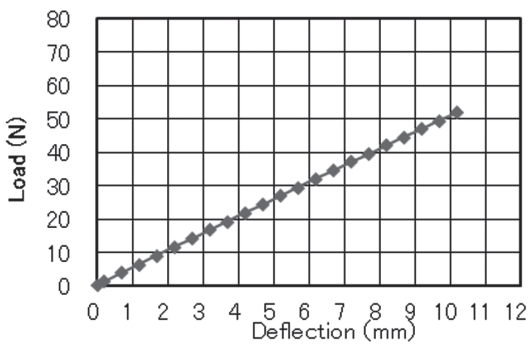

(c) SUS304-WPB $\phi 1.0 \mathrm{~mm}$.

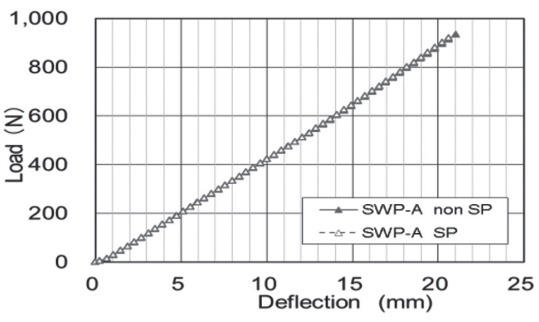

(d) SWP-A $\phi 4.0 \mathrm{~mm}$.

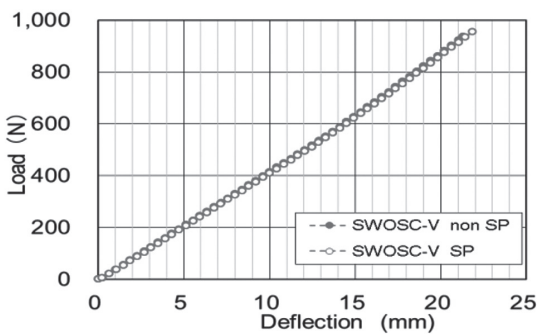

(e) SWOSC-V $\phi 4.0 \mathrm{~mm}$.

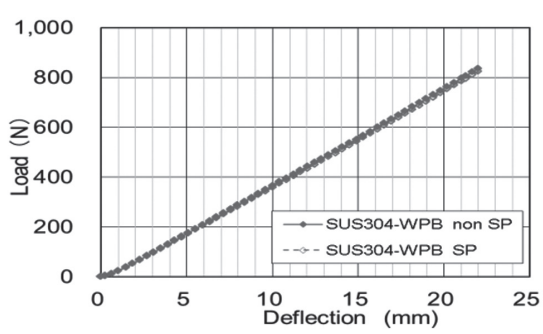

(f) SUS304-WPB $\phi 4.0 \mathrm{~mm}$.
Fig. 3-6にショットピーニングを施したばねのX線法を用 いた残留応力測定結果を示す測定はばねの内径側を主応力 方向で行い，SWP-A及びSWOSC-Vのばねは並傾法により， SUS304-WPBのばねはX線2D法により行った.その結果，ば ね表層に圧縮残留応力が付与されていることを確認できた。

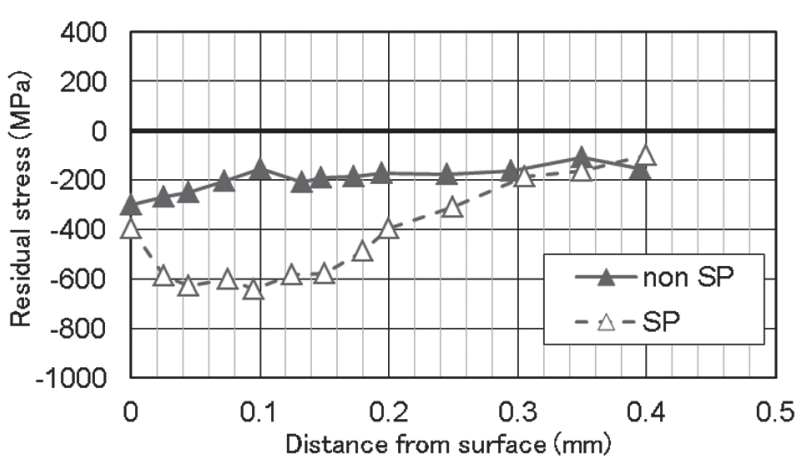

([SP]Shot peened, [non SP $]$ not Shot peened) (a) SWP-A $\phi 4.0 \mathrm{~mm}$.

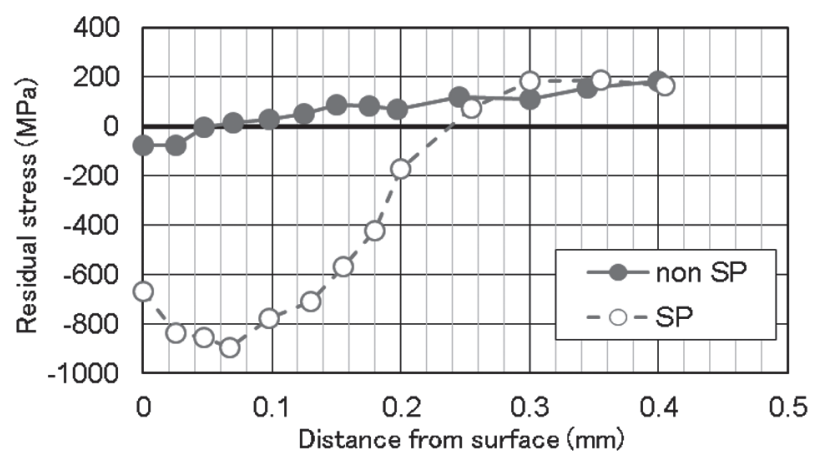

(b) SWOSC-V $\phi 4.0 \mathrm{~mm}$

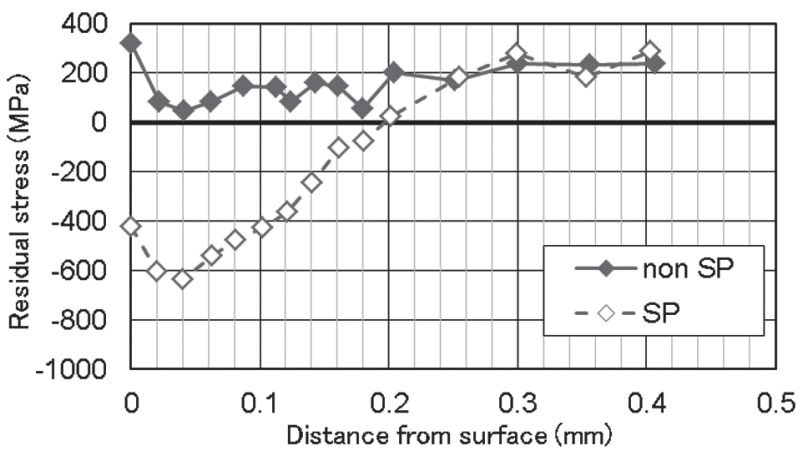

(c) SUS304-WPB $\phi 4.0 \mathrm{~mm}$.

Fig. 3-6 Residual stress distributions of specimen springs.

Fig. 3-5 Load-Deflection diagrams of specimens. 


\section{3 温間へたり試験方法}

\subsection{1 試験条件}

Table 3-6 に試験条件を示す. 締付応力, 試験温度, 締 付時間は, 従来, 実施されてきた試験条件を参考に決定した。

Table 3-6 Conditions of spring set test.

\begin{tabular}{|c|c|c|c|c|c|}
\hline Materials & $\begin{array}{c}\text { Wire } \\
\text { diameter } \\
(\mathrm{mm})\end{array}$ & $\begin{array}{l}\text { Shot } \\
\text { peening }\end{array}$ & $\begin{array}{c}\text { Clamping } \\
\text { stress }(\mathrm{MPa})\end{array}$ & $\begin{array}{c}\text { Test } \\
\text { temperature } \\
\left({ }^{\circ} \mathrm{C}\right)\end{array}$ & $\begin{array}{c}\text { Clamping } \\
\text { time } \\
\text { (hour) }\end{array}$ \\
\hline \multirow{6}{*}{$\begin{array}{c}\text { SWP-A } \\
\text { SWOSC-V }\end{array}$} & \multirow{4}{*}{$\begin{array}{l}\phi 1.0 \\
\phi 4.0\end{array}$} & \multirow{4}{*}{ Non } & 600 & \multirow{4}{*}{$\begin{array}{l}100 \\
150 \\
200\end{array}$} & \multirow{12}{*}{$\begin{array}{c}24 \\
48 \\
96 \\
312\end{array}$} \\
\hline & & & 700 & & \\
\hline & & & 800 & & \\
\hline & & & 900 & & \\
\hline & \multirow{2}{*}{$\phi 4.0$} & \multirow{2}{*}{ Treated } & 600 & \multirow{2}{*}{$\begin{array}{l}100 \\
200\end{array}$} & \\
\hline & & & 900 & & \\
\hline \multirow{6}{*}{$\begin{array}{l}\text { SUS304 } \\
\text {-WPB }\end{array}$} & \multirow{4}{*}{$\begin{array}{l}\phi 1.0 \\
\phi 4.0\end{array}$} & \multirow{4}{*}{ Non } & 500 & \multirow{4}{*}{$\begin{array}{l}200 \\
300 \\
400\end{array}$} & \\
\hline & & & 600 & & \\
\hline & & & 700 & & \\
\hline & & & 800 & & \\
\hline & \multirow{2}{*}{$\phi 4.0$} & \multirow{2}{*}{ Treated } & 500 & \multirow{2}{*}{$\begin{array}{l}200 \\
400\end{array}$} & \\
\hline & & & 800 & & \\
\hline
\end{tabular}

\subsection{2 試験手順}

本委員会で実施した温間へたり試験手順を示す。

[手順1］ばねの寸法測定 (Fig. 3-7)

・外径測定は，ノギスを用いて 2 方向を測定 $\left(90^{\circ}\right) し$ ，そ の平均值を採用する。

・自由長は, 荷重0.3Nを付加時の高さを測定し採用する. ・線径はミルシートのトップ/エンドの平均值を採用する。

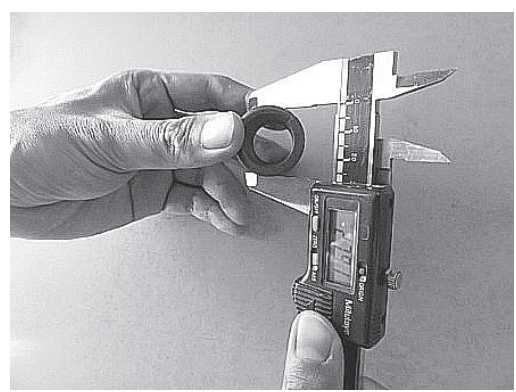

Fig.3-7 Measuring outer diameters of specimen spring.

[乎順2］セッチング高さ算出及びセッチング実施

・各線種ごとに荷重-たわみ線図を作成する $(\mathrm{n}=2)$.

・荷重－たわみ線図からセッチング応力での高さを読み 取り，2本の平均值をセッチング高さとする。

・セッチングは2秒間保持して3回実施する.

\section{[手順3］締付高さの算出}

・セッチングしたばねを用いて，荷重-たわみ線図を作成 する. $(\mathrm{n}=2)$

・各締付応力時の 2 本のばね高さの平均值で算出する.

・この時の高さを, 同じ条件の試験に適用する.

以上の手順で使用する予測計算式は，次の通りである。 $\tau=\frac{8 \cdot P \cdot D}{\pi \cdot d^{3}}$

$\tau$ : 締付応力 $[\mathrm{MPa}]$

$\mathrm{P}$ : 荷重 $[\mathrm{N}]$

$\mathrm{D}$ : コイル平均径 $[\mathrm{mm}]$

$\mathrm{d}:$ 線径 $[\mathrm{mm}]$

[手順4]へたり測定試験結果の算出

・荷重損失 $\Delta \mathrm{P}$ 求め, 残留せん断ひずみ $\gamma$ を算出し, こ の值をへたりの指標とする，算出式は次の通り。

$$
\gamma=\frac{8 \cdot \Delta \mathrm{P} \cdot \mathrm{D}}{\pi \cdot \mathrm{d}^{3} \cdot G}
$$

$\gamma:$ 残留せん断ひずみ $[\%]$

$\mathrm{D}$ : コイル平均径 $[\mathrm{mm}]$

$\mathrm{G}:$ 横弾性係数 $\left[\mathrm{N} / \mathrm{mm}^{2}\right]$

\subsection{3 締付試験方法，及び温間加熱・冷却方法}

Fig.3-8に線径 $\phi 1.0$ 及び4.0mmのばねの締付方法をそれぞ れ示した。いずれも高さを一定に保持して締付試験を行え るようにしている。 クを4箇所に配置し， $\phi 4.0 \mathrm{~mm}$ のばねでは指定長さのパイ プを使用して締付試験を行った。加熱試験には恒温槽を用 いた。ばねが互いに重ならないように間隔をあけて配置し， 冷却は炉から取り出した後, 空冷して行い, サンプルが常 温になるまで放置して固定治具からばねを取り外した。

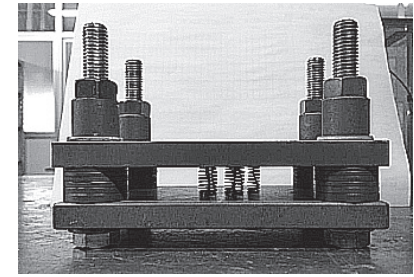

(a) Wire dimeter $\phi 1.0 \mathrm{~mm}$

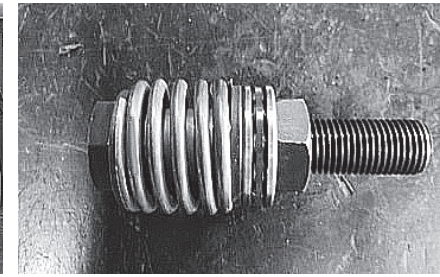

(b) Wire dimeter $\phi 4.0 \mathrm{~mm}$
Fig. 3-8 Retaining method of specimen springs.

\subsection{4 長時間側の試験方法}

試験は一つのばねを使用して時間経過ごとにへたり量を 測定して，再度，締付試験を継続する「間欠法」を採用した。 温間へたり量が間欠法と連続法とで差がないことは過去の 文献 ${ }^{16)} よ り$ 明確にされている。

\section{4 温間へたり試験結果及び考察 3.4.1各線種（鋼種）の試験結果}

Fig. 3-9((a)〜 (f)) にSWP-AのSP無しのばねの試験結果 を, Fig. 3-10((a)〜 (f))にSWOSC-VのSP無しのばねの試験 結果を, Fig. 3-11( (a)〜 (f)) にSUS304-WPBのSP無しのば ねの温間へたり試験結果を示す。すべての結果において, 締付温度が高いほど, 締付応力が高いほど残留せん断ひず み $\gamma$ は大くなることを確認した。 


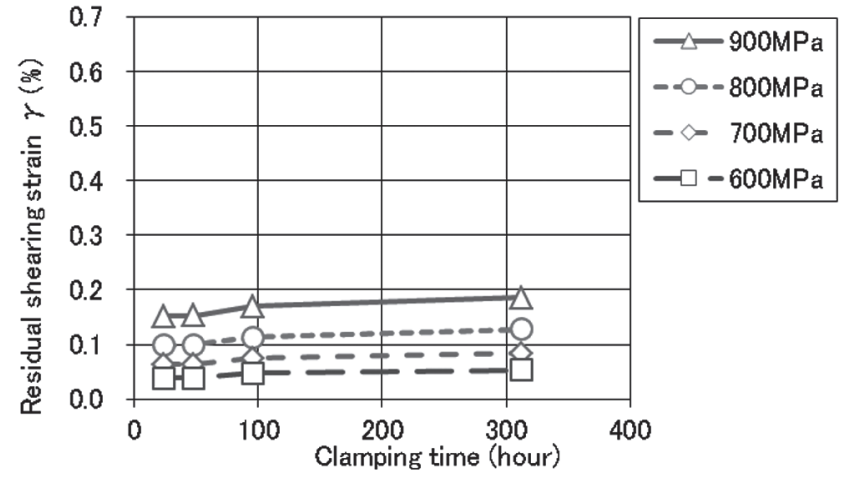

Fig. 3-9 (a) SWP-A $\phi 1.0 \mathrm{~mm}$ springs. $\left(100^{\circ} \mathrm{C}\right)$

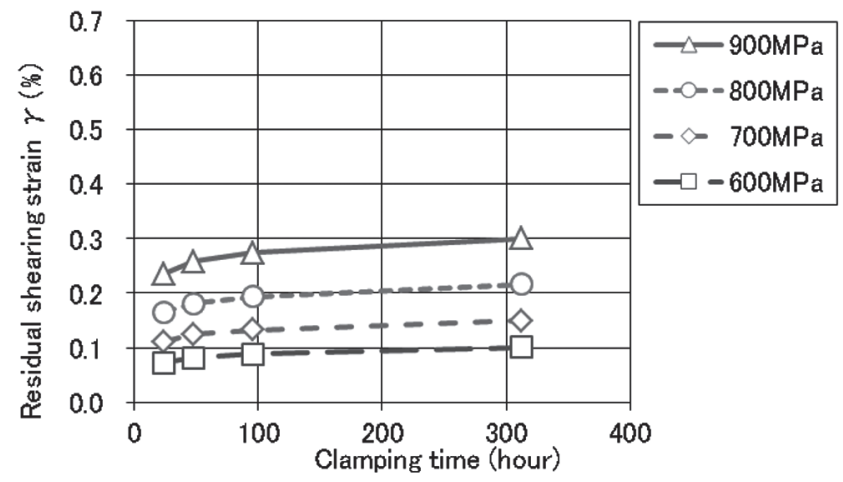

Fig. 3-9 (b) SWP-A $\phi 1.0 \mathrm{~mm}$ springs. $\left(150^{\circ} \mathrm{C}\right)$

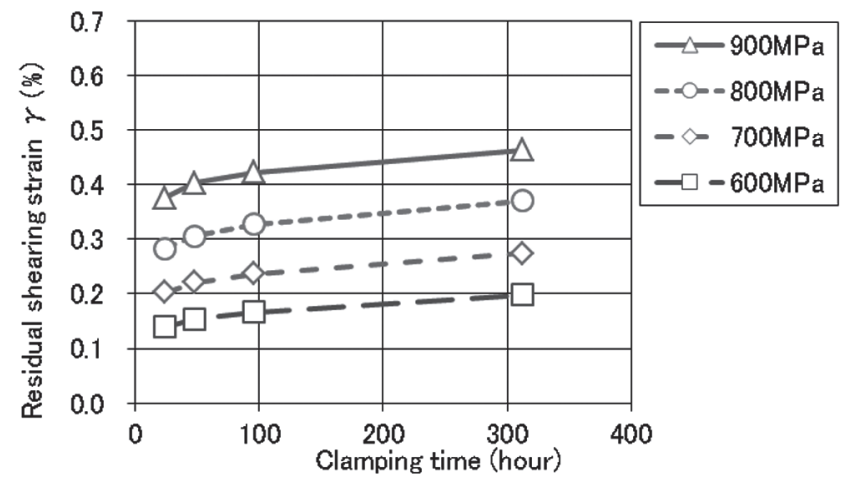

Fig. 3-9 (c) SWP-A $\phi 1.0 \mathrm{~mm}$ springs. $\left(200^{\circ} \mathrm{C}\right)$

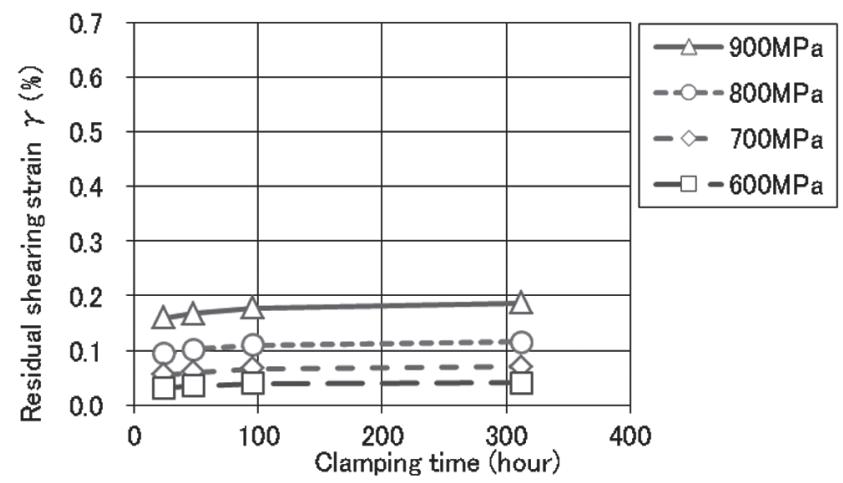

Fig. 3-9 (d) SWP-A $\phi 4.0 \mathrm{~mm}$ springs. $\left(100^{\circ} \mathrm{C}\right)$

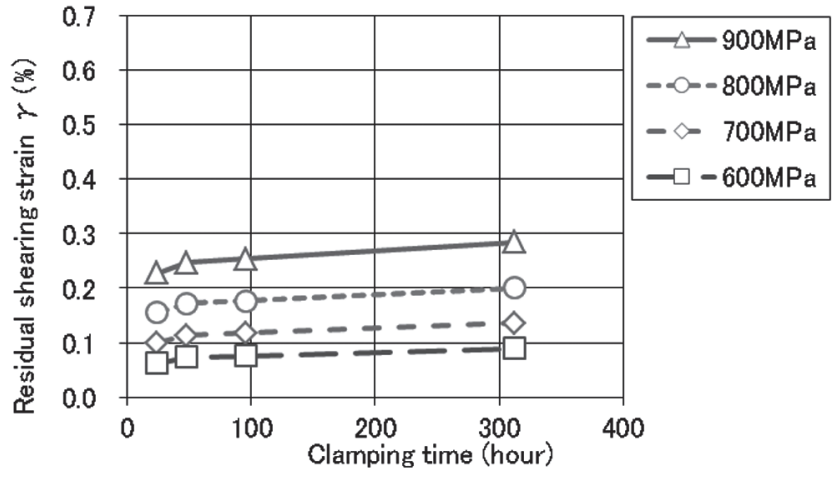

Fig. 3-9 (e) SWP-A $\phi 4.0 \mathrm{~mm}$ springs. $\left(150^{\circ} \mathrm{C}\right)$

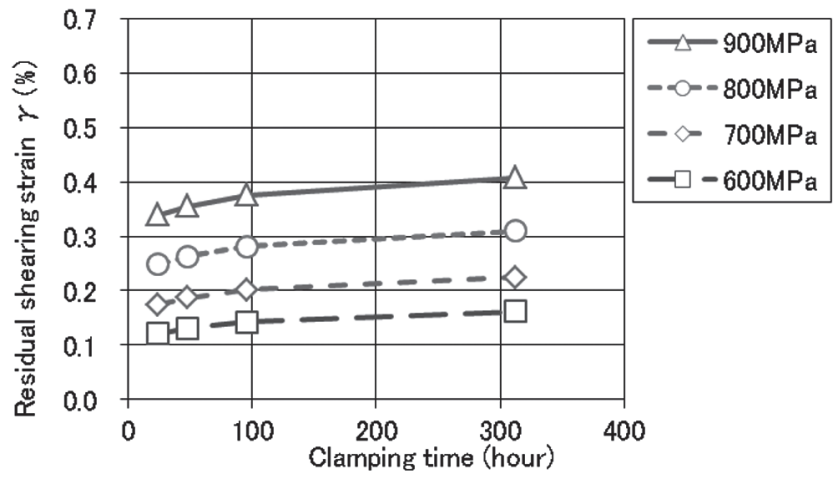

Fig. 3-9 (f) SWP-A $\phi 4.0 \mathrm{~mm}$ springs. $\left(200^{\circ} \mathrm{C}\right)$

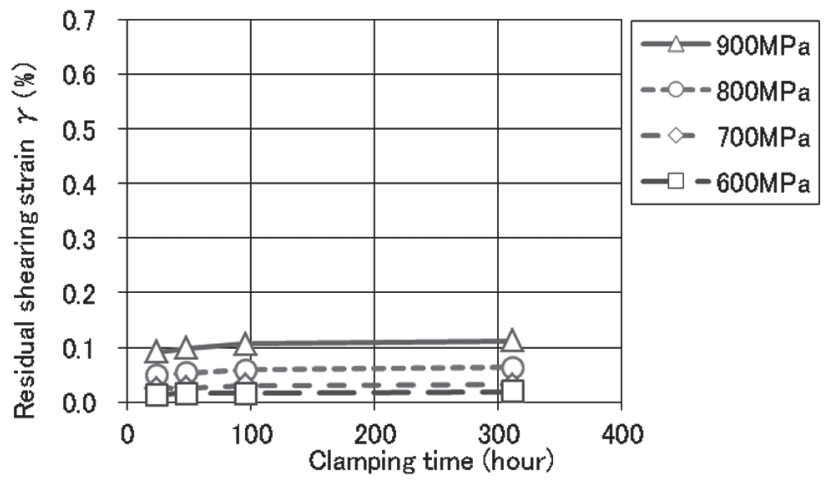

Fig. 3-10 (a) SWOSC-V $\phi 1.0 \mathrm{~mm}$ springs. $\left(100^{\circ} \mathrm{C}\right)$

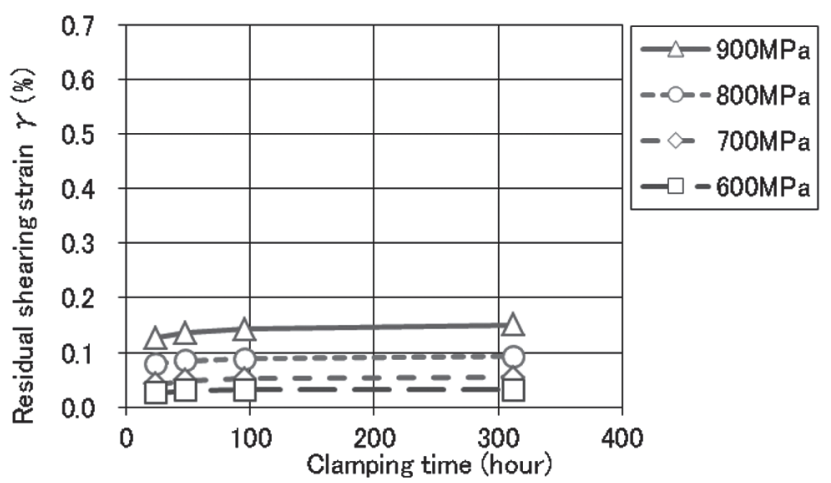

Fig. 3-10 (b) SWOSC-V $\phi 1.0 \mathrm{~mm}$ springs. $\left(150^{\circ} \mathrm{C}\right)$ 


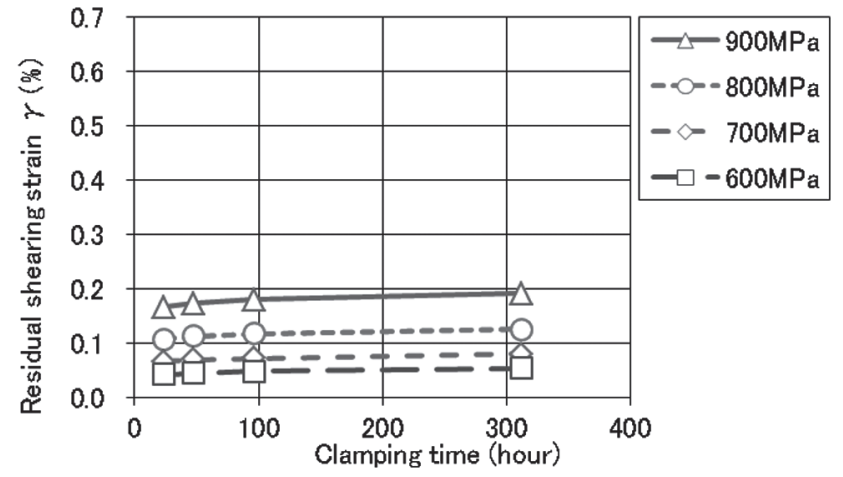

Fig. 3-10 (c) SWOSC-V $\phi 1.0 \mathrm{~mm}$ springs. $\left(200^{\circ} \mathrm{C}\right.$ )

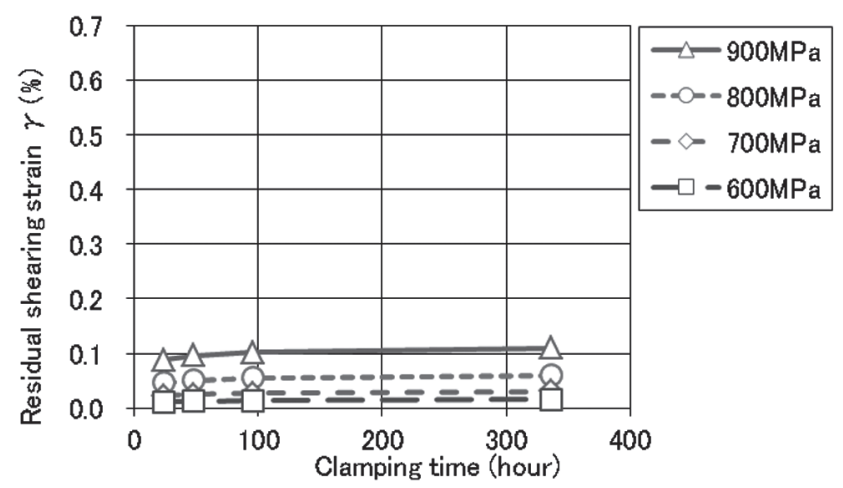

Fig. 3-10 (d) SWOSC-V $\phi 4.0 \mathrm{~mm}$ springs. $\left(100^{\circ} \mathrm{C}\right)$

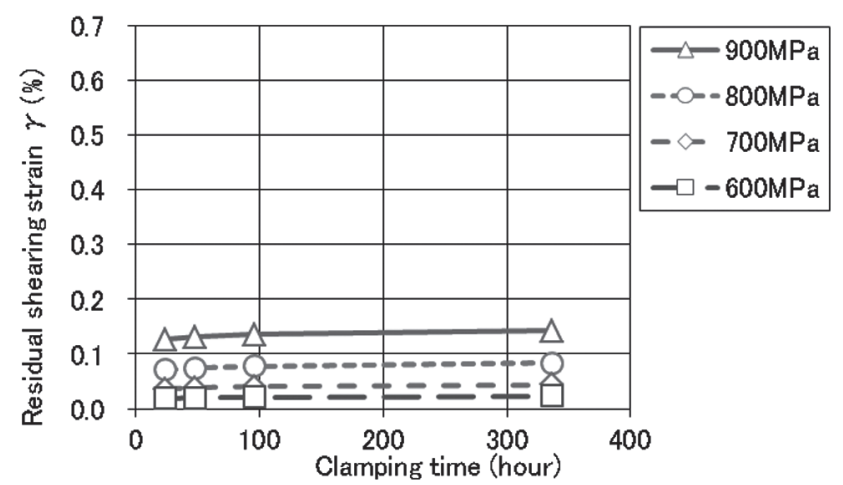

Fig. 3-10 (e) SWOSC-V $\phi 4.0 \mathrm{~mm}$ springs. $\left(150^{\circ} \mathrm{C}\right)$

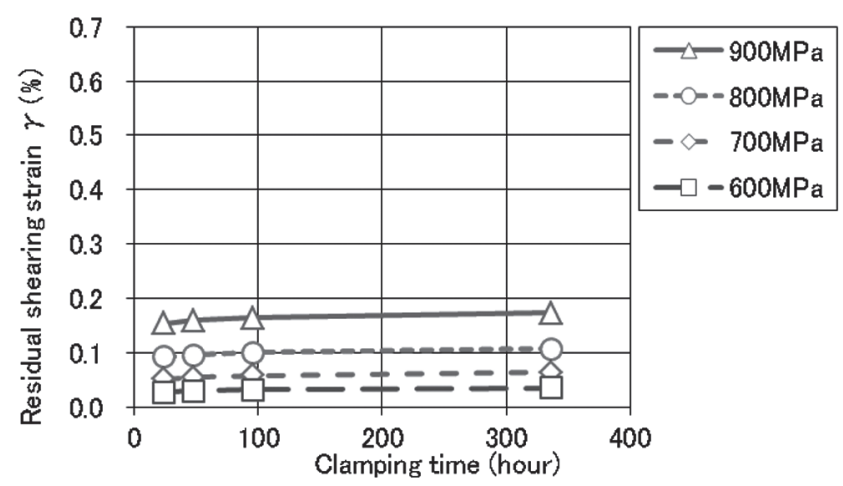

Fig. 3-10 (f) SWOSC-V $\phi 4.0 \mathrm{~mm}$ springs. $\left(200^{\circ} \mathrm{C}\right)$

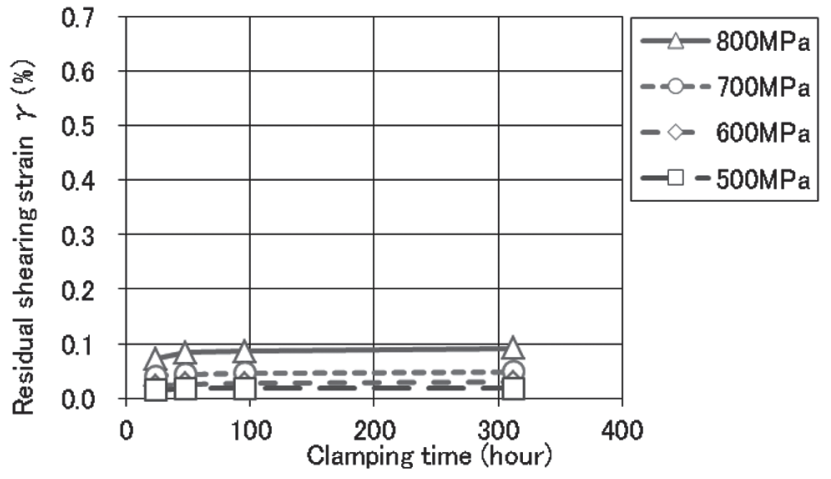

Fig. 3-11 (a) SUS304-WPB $\phi 1.0 \mathrm{~mm}$ springs. $\left(100^{\circ} \mathrm{C}\right)$

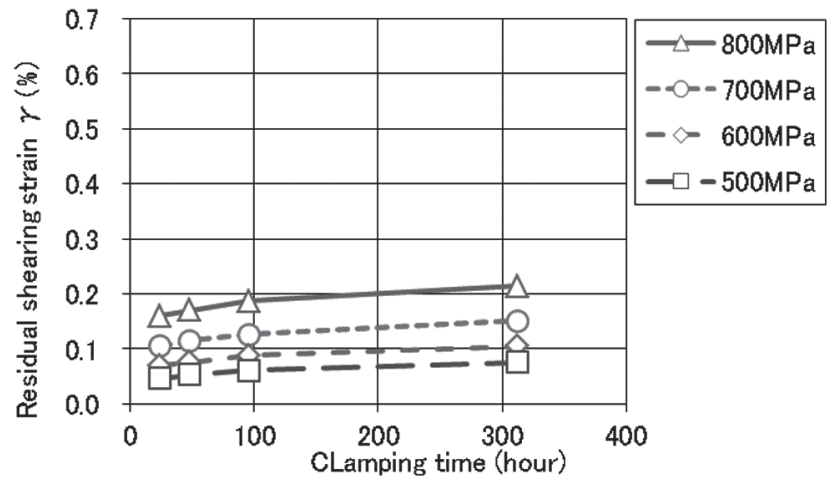

Fig. 3-11 (b) SUS304-WPB $\phi 1.0 \mathrm{~mm}$ springs. $\left(150^{\circ} \mathrm{C}\right)$

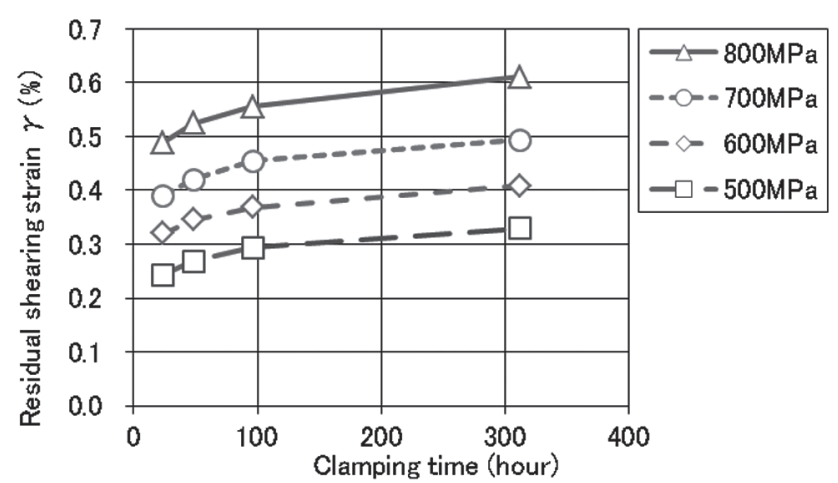

Fig. 3-11 (c) SUS304-WPB $\phi 1.0 \mathrm{~mm}$ springs. $\left(200^{\circ} \mathrm{C}\right)$

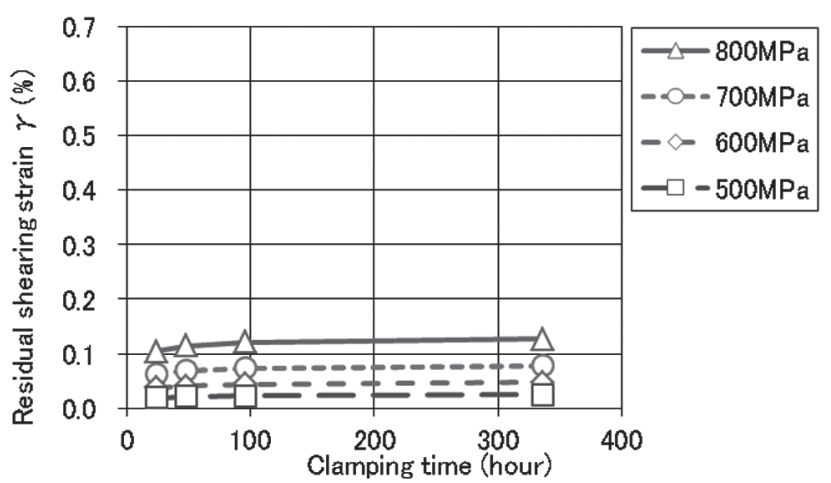

Fig. 3-11 (d) SUS304-WPB $\phi 4.0 \mathrm{~mm}$ springs. $\left(100^{\circ} \mathrm{C}\right)$ 


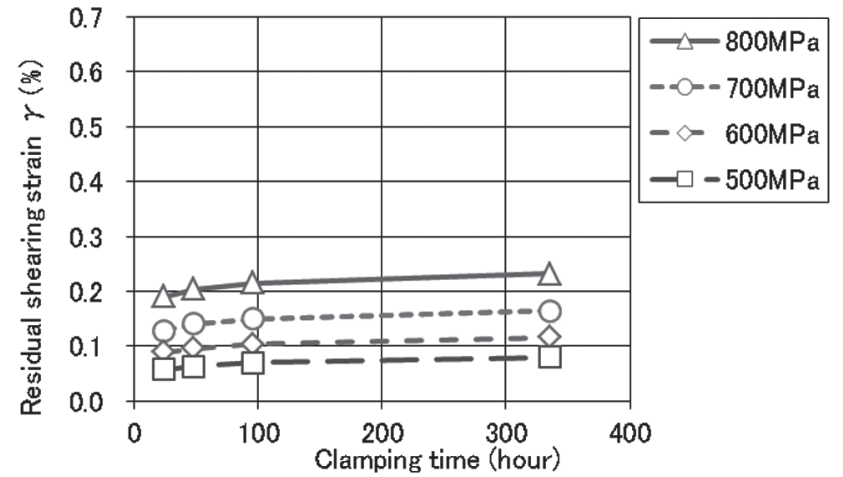

Fig. 3-11 (e) SUS304-WPB $\phi 4.0 \mathrm{~mm}$ springs. $\left(150^{\circ} \mathrm{C}\right)$

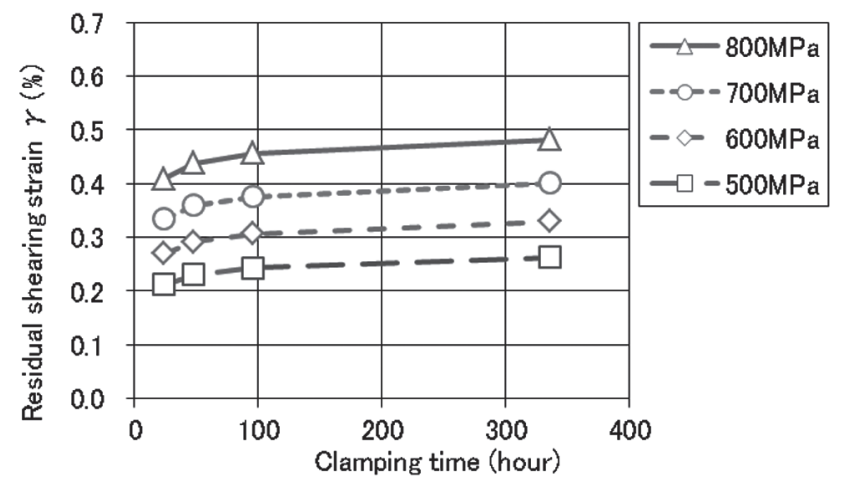

Fig. 3-11 (f) SUS304-WPB $\phi 4.0 \mathrm{~mm}$ springs. $\left(200^{\circ} \mathrm{C}\right)$

\subsection{2 線種 (鋼種) 差の比較と考察}

\section{これらの結果をもとに，以下で比較検討を行う。}

Fig. 3-12( (a)〜 (f)) に線径 $\phi 1.0 \mathrm{~mm}$ 及び $\phi 4.0 \mathrm{~mm}$ の線種 での比較結果を示す。比較をするにあたり，3線種が同じ条 件になる条件として, 締付温度 $200^{\circ} \mathrm{C}$, 締付応力 $600 \mathrm{MPa}$ ら800MPaを採用した。

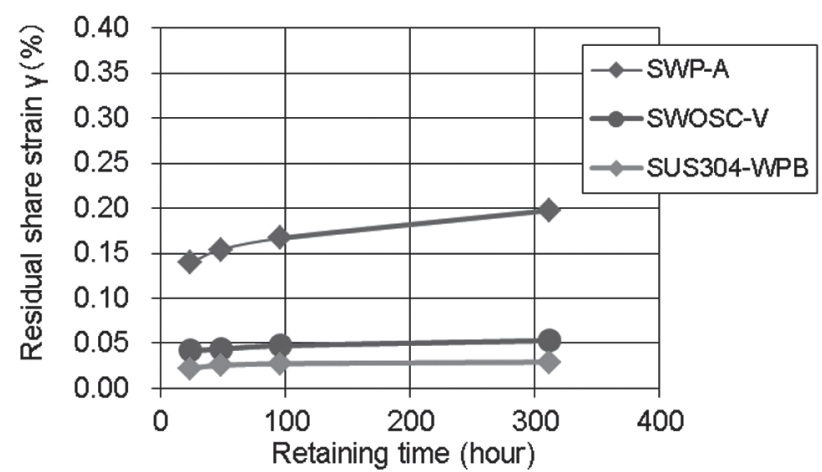

Fig. 3-12 (a) Comparison results of three types materials of residual share strain. ( $\phi 1.0 \mathrm{~mm}$ springs, non SP, $200^{\circ} \mathrm{C}, 600 \mathrm{MPa}$ )

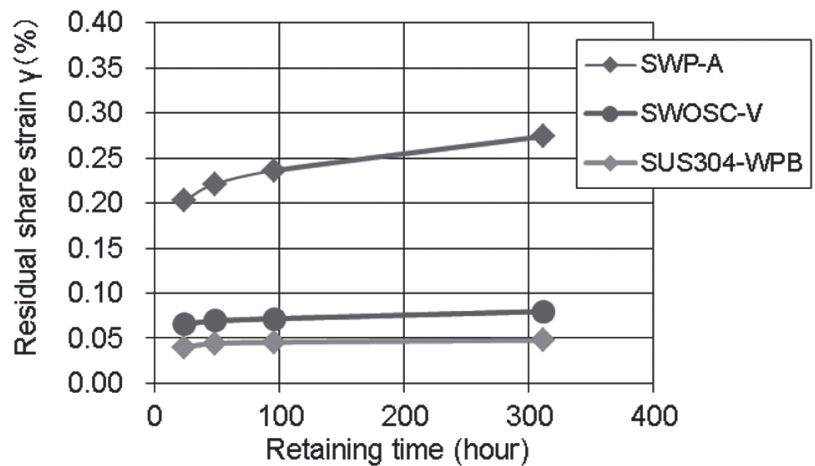

Fig. 3-12 (b) Comparison results of three types materials of residual share strain. ( $\phi 1.0 \mathrm{~mm}$ Springs, non SP, $200^{\circ} \mathrm{C}, 700 \mathrm{MPa}$ )

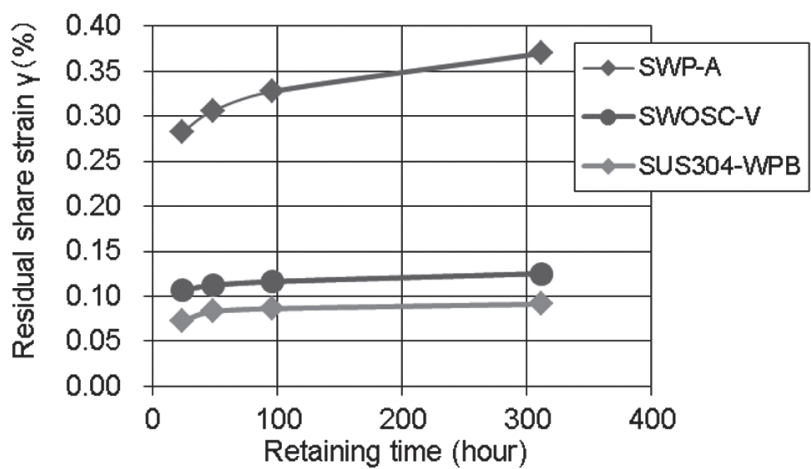

Fig. 3-12 (c) Comparison results of three types materials of residual share strain. ( $\phi 1.0 \mathrm{~mm}$ springs, non $\mathrm{SP}, 200^{\circ} \mathrm{C}, 800 \mathrm{MPa}$ )

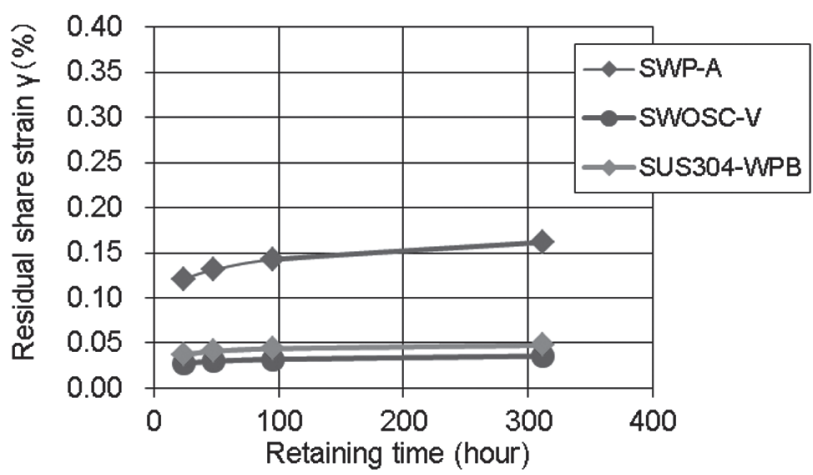

Fig. 3-12 (d) Comparison results of three types materials of residual share strain. ( $\phi 4.0 \mathrm{~mm}$ springs, non SP, $200^{\circ} \mathrm{C}, 600 \mathrm{MPa}$ )

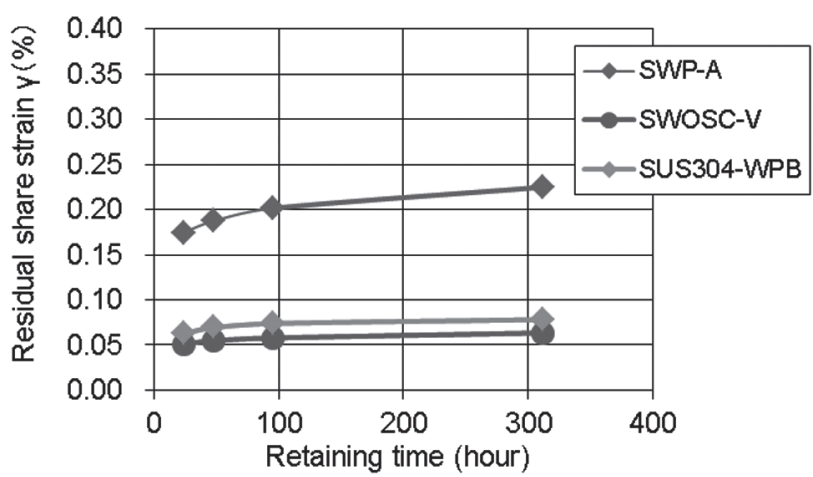

Fig. 3-12 (e) Comparison results of three types materials of residual share strain. ( $\phi 4.0 \mathrm{~mm}$ springs, non $\mathrm{SP}, 200^{\circ} \mathrm{C}, 700 \mathrm{MPa}$ ) 


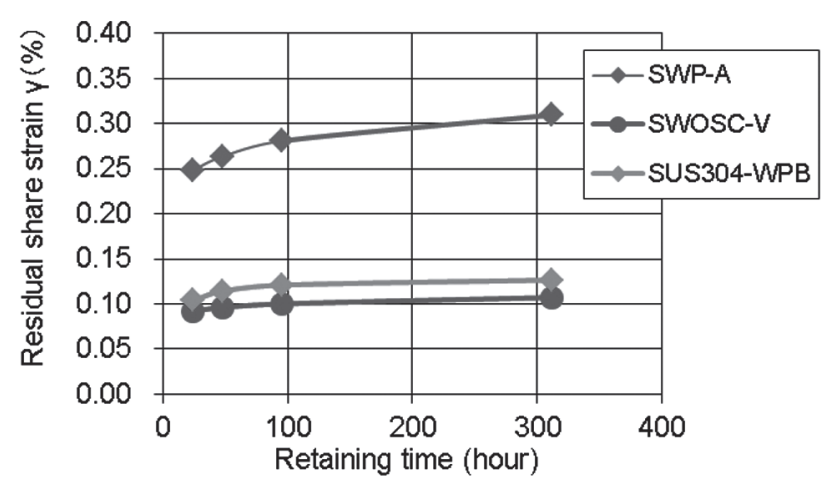

Fig. 3-12 (f) Comparison results of three types materials of residual share strain. $(\phi 4.0 \mathrm{~mm}$ springs, non $\mathrm{SP}, 200^{\circ} \mathrm{C}, 800 \mathrm{MPa}$ )

線径 $\phi 1.0 \mathrm{~mm}$ では残留せん断ひずみ $\gamma$ の大きさが, SWP-A > SWOSC-V>SUS304-WPBの順であったが, 線 径 $\phi 4.0 \mathrm{~mm}$ ではSWP-A >SUS304-WPB >SWOSC-Vの順と なって傾向が異なり, SWOSC-VとSUS304-WPBが逆転す る事象についてばねの硬さに着目して検討した。

Fig. 3-13に線径 $\phi 1.0 \mathrm{~mm}$ 及゙Fig. 3-14に $\phi 4.0 \mathrm{~mm}$ のばね の硬さ測定結果を示す。この結果から, 線径 $\phi 1.0 \mathrm{~mm}$ のば ねの硬さが $\phi 4.0 \mathrm{~mm}$ のばねよりも硬くなっていることを確 認できた。また，SWOSC-VとSUS304-WPBの線径での硬さ の差に着目してみると, 線径 $\phi 1.0 \mathrm{~mm}$ に比べて $\phi 4.0 \mathrm{~mm}$ の 方が硬さの差は大きい，このように硬さが残留せん断ひず みノに影響することを実データでも確認できた。

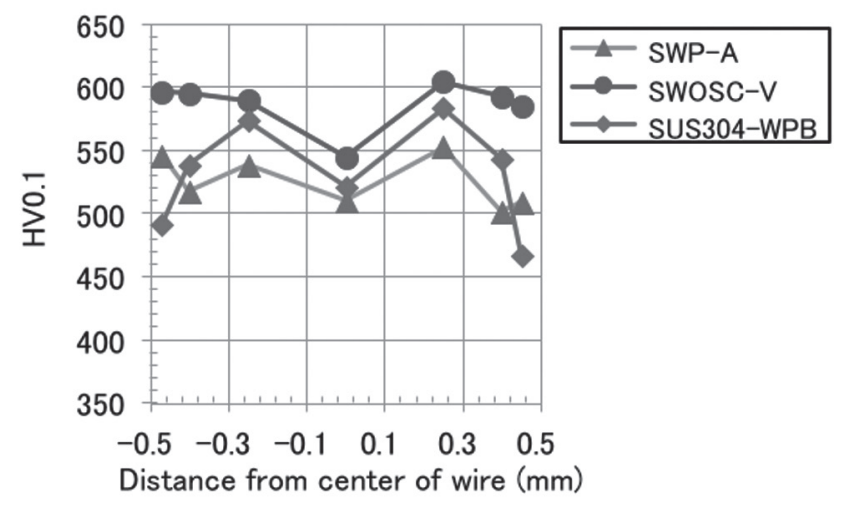

Fig. 3-13 Vickers Hardness of $\phi 1.0 \mathrm{~mm}$ springs non SP.

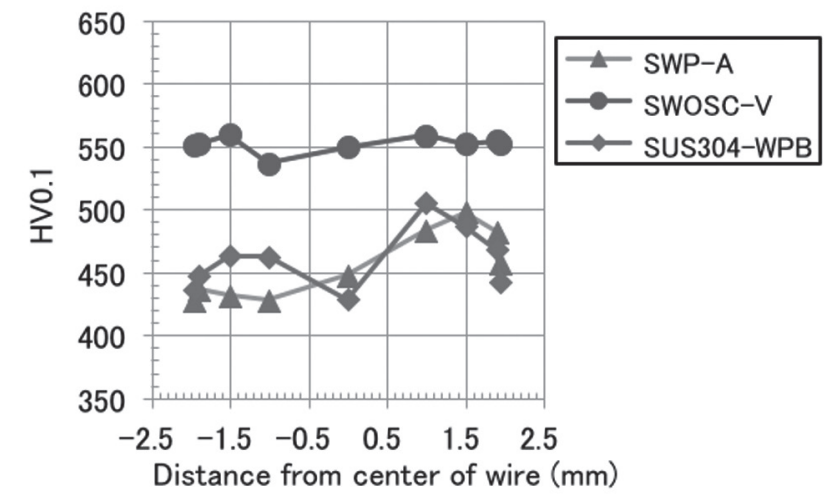

Fig. 3-14 Vickers Hardness of $\phi 4.0 \mathrm{~mm}$ springs non SP.

\subsection{3 線径による比較}

各線種の線径 $\phi 1.0 \mathrm{~mm}$ と $\phi 4.0 \mathrm{~mm}$ のばねについて, 加熱 温度 $100,150,200^{\circ} \mathrm{C}$, 締付時間 $24,48,96,312 \mathrm{~h}$ で温間へたり試 験を行い，残留せん断ひずみ $\gamma$ に及ぼす負荷応力の影響 を比較した. Fig. 3-15((a)〜 (d)) にSWP-Aの試験結果を, Fig. 3-16((a) 〜 (d)) にSWOSC-Vの試験結果を, Fig. 3-17 ((a)〜 (d))にSUS304-WPBの試験結果をまとめて示す.

これらの試験結果で, SWP-A及びSWOSC-Vでは, 残留 せん断ひずみ $\gamma$ が $\phi 1.0 \mathrm{~mm}>\phi 4.0 \mathrm{~mm}$ という関係を示した。 一方，SUS304-WPBでは，締付温度によって結果が異なり， 締付温度 $200^{\circ} \mathrm{C}$ 及び $300^{\circ} \mathrm{C}$ では $\phi 1.0 \mathrm{~mm}<\phi 4.0 \mathrm{~mm}$ となり, 締 付温度 $400^{\circ} \mathrm{C}$ では $\phi 1.0 \mathrm{~mm}>\phi 4.0 \mathrm{~mm}$ という結果となった。

先の検証でばねの硬さ測定を行い，その結果をFig. 3-13 及びFig. 3-14に示したが,その時の硬さデー夕は $\phi 1.0 \mathrm{~mm}>$ 中4.0mmであった，すなわち，硬さが高い方が残留せん断 ひずみ $\gamma$ がさくなるとの考えもあるが，今回は反対の結 果が得られ，硬さだけでは説明がつかないことがわかった。

そこで, 線径によって残留せん断ひずみ $\gamma$ に違いが表 れる要因として，セッチングの効果に差が生じていると考 えた。今回のセッチング条件は過去の試験条件を採用し, SWP-A及びSWOSC-Vについては1000MPa，SUS304-WPB については850MPaで行った。 セッチングの効果については 残留応力の影響と考えられており，またセッチングにより 諸特性が変化することも知られている22)，今回の活動では 材料の比較検証ができていないため, 今後, $\mathrm{S}-\mathrm{S}$ 曲線の作 成を含めて試験検証を追加する予定である.

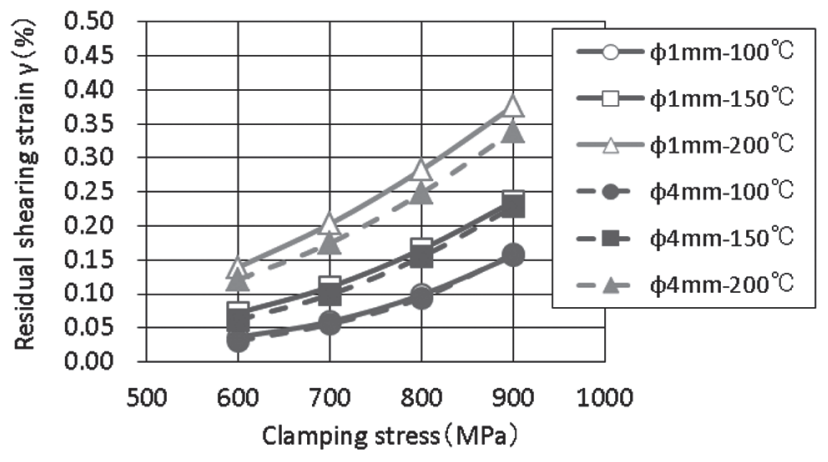

Fig. 3-15 (a) SWP-A[24h].

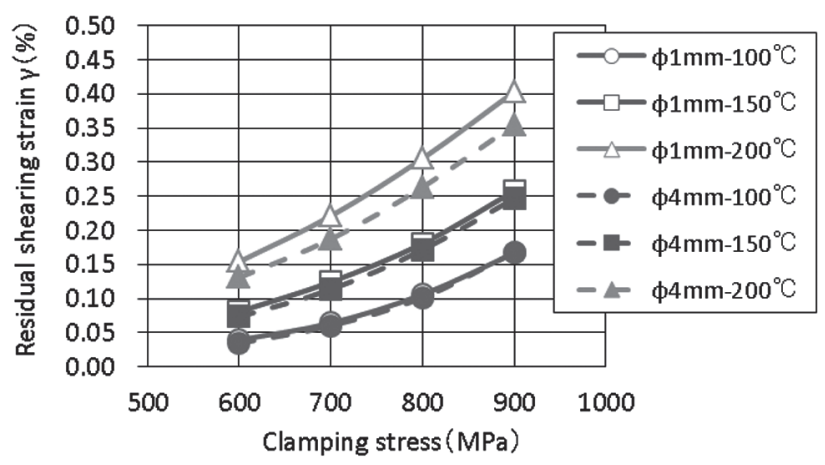

Fig. 3-15 (b) SWP-A[48h]. 


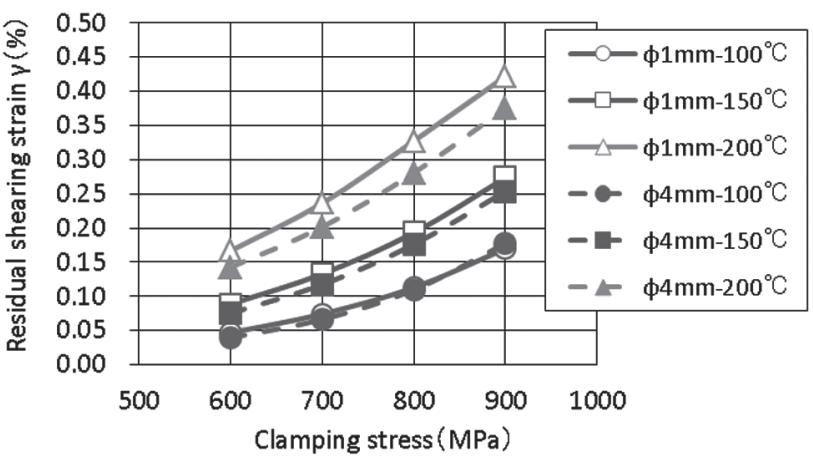

Fig. 3-15 (c) SWP-A[96h].

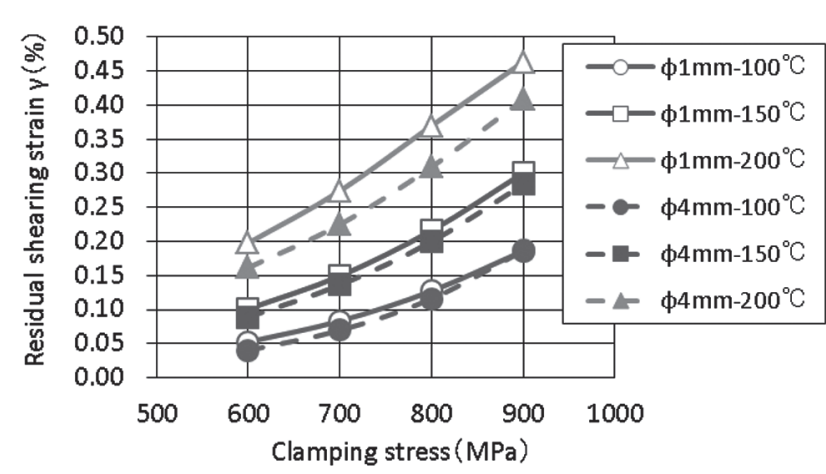

Fig. 3-15 (d) (d)SWP-A[312h].

Fig. 3-15 Comparison of residual shear strain between $\phi$ $1.0 \mathrm{~mm}$ and $\phi 4.0 \mathrm{~mm}$ springs.

(SWP-A [24, 48, 96, 312h])

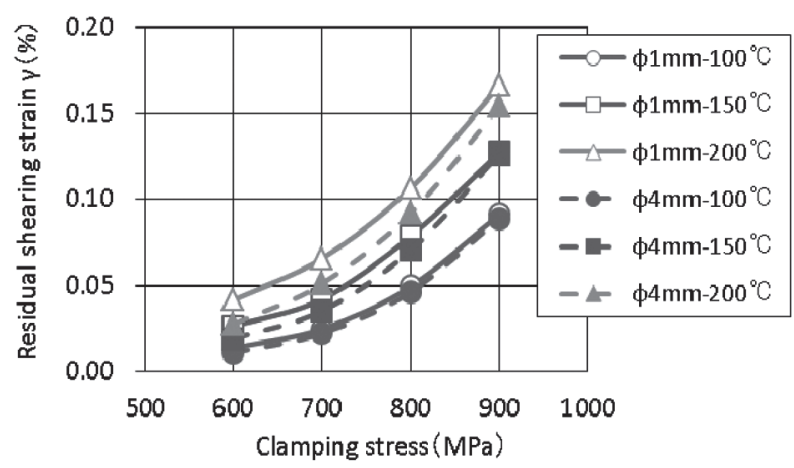

Fig. 3-16 (a) SWOSC-V[24h].

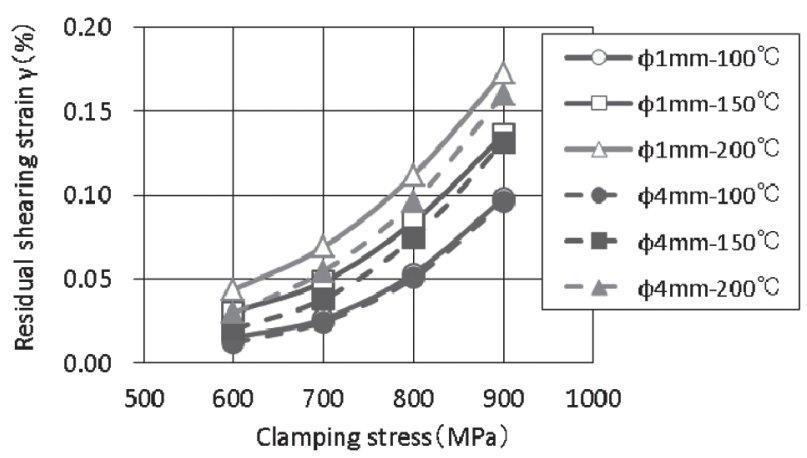

Fig. 3-16 (b) SWOSC-V[48h].

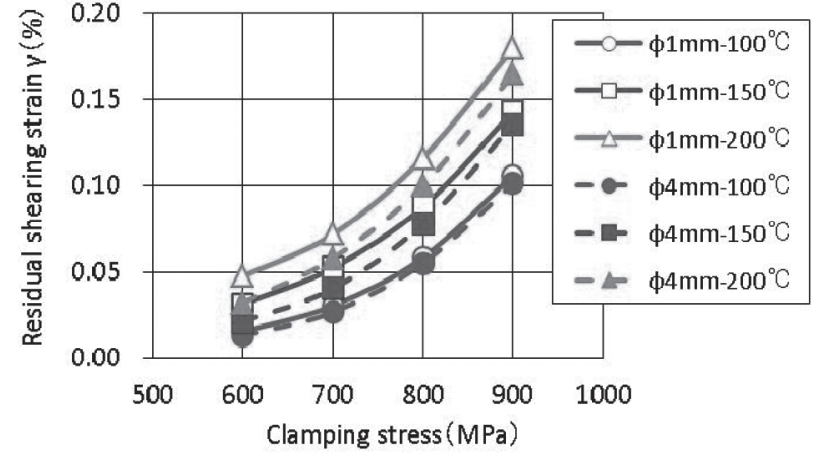

Fig. 3-16 (c) SWOSC-V[96h].

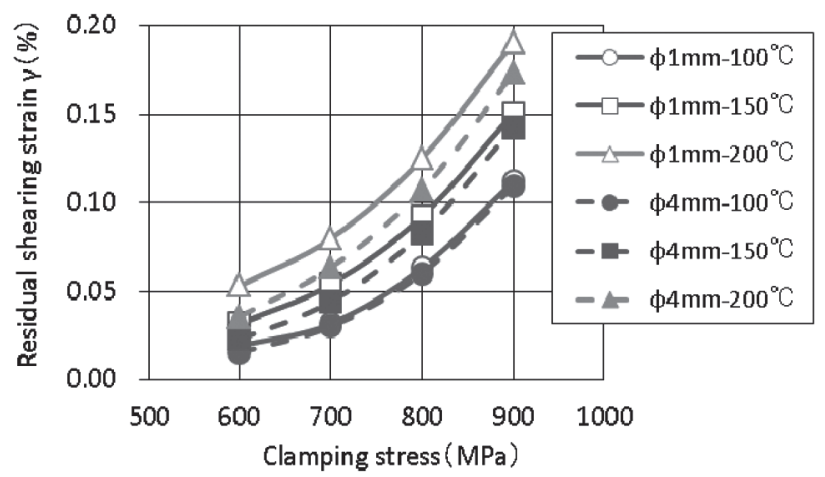

Fig. 3-16 (d) SWOSC-V[312h].

Fig. 3-16 Comparison of residual shear strain between $\phi$ $1.0 \mathrm{~mm}$ and $\phi 4.0 \mathrm{~mm}$ springs. (SWOSC-V $[24,48,96,312 \mathrm{~h}]$ )

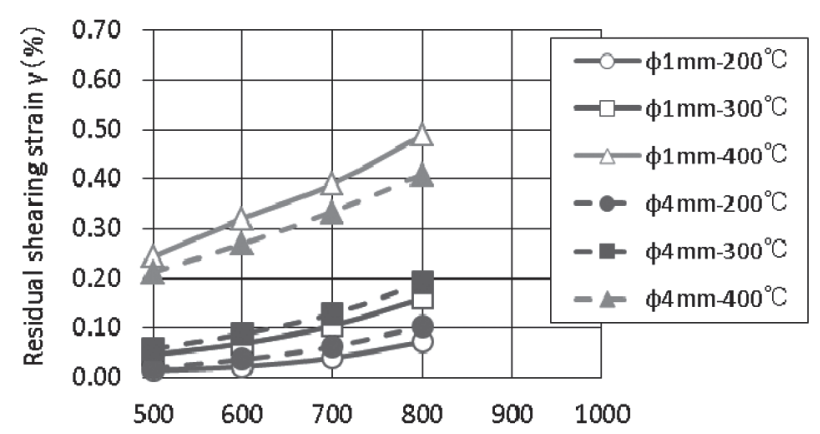

Fig. 3-17 (a) SUS304-WPB [24h].

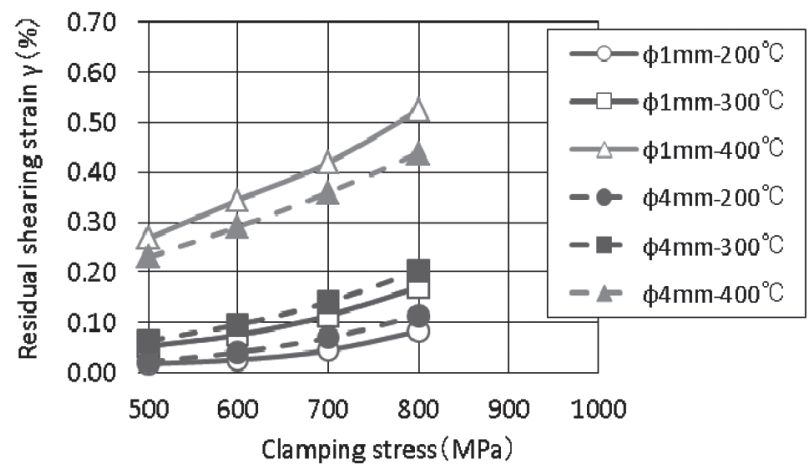

Fig. 3-17 (b) SUS304-WPB [48h]. 


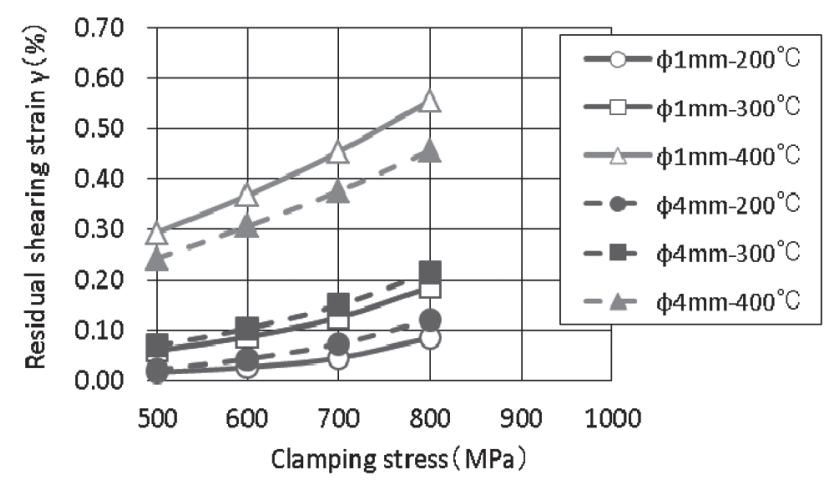

Fig. 3-17 (c) SUS304-WPB[96h].

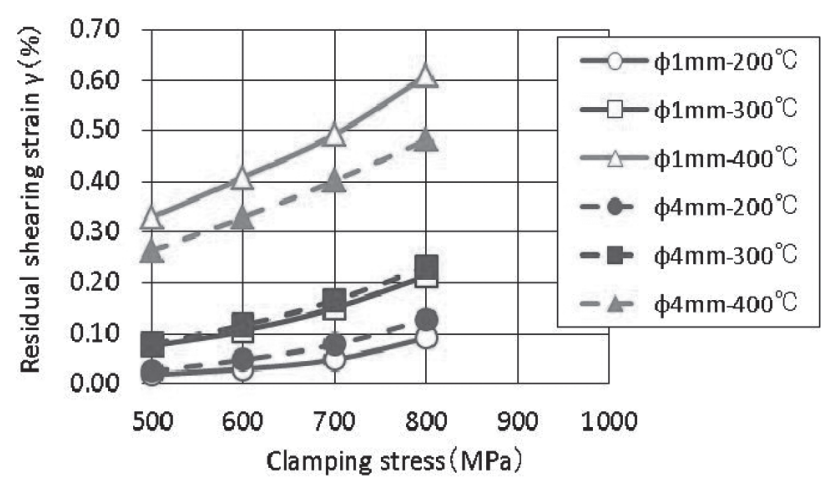

Fig. 3-17 (d) SUS304-WPB[312h].

Fig. 3-17((a) (d)) Comparison of residual shear strain between $\phi 1.0 \mathrm{~mm}$ and $\phi 4.0 \mathrm{~mm}$ springs. (SUS304-WPB[24, 48, 96, 312h])

\subsection{4 ショットピーニング有無の比較}

各線種のばねについてショットピーニング処理有り・無 しの場合の残留せん断ひずみ $\gamma$ を測定して, 残留せん断ひ ずみ $\gamma$ に及ぼすショットピーニングの影響を検証した。

Fig. 3-18 ((a) (b)) にSWP-Aでの測定結果を示す. 締付温 度 $100^{\circ} \mathrm{C}$ では差はないが, $200^{\circ} \mathrm{C} て ゙ は$ 残留せん断ひずみ $\gamma$ が 増加した。これは，ショットピーニングにより付与された 残留応力が，温間へたり試験中に，コイリング後の低温焼 なまし処理温度に近い条件で長時間保持されたことから減 少してねじり降伏点が低下したためと考えられる22.23)

Fig. 3-19 ((a) (b)) にSWOSC-Vでの測定結果を示す. SWP-Aの結果と同様の傾向が見られたが, ショットピー

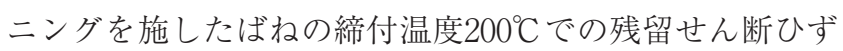
み $\gamma$ の増加量が大きくなった。 これは, ショットピーニン グに付与された残留応力がSWOSC-Vのほうが大きいこと から可動転位量が多くなったためと考えられる.

Fig. 3-20((a) (b)) にSUS304-WPBでの測定結果を示す. 締付温度 $200^{\circ} \mathrm{C}$ と $400^{\circ} \mathrm{C}$ では, ショットピーニングによる差 は現れなかった。これは締付温度が $400^{\circ} \mathrm{C}$ と高いため,ショッ トピーニングにより付与した残留応力が消失して処理無し ばねと同様の結果となったと考元られる。

これらの結果から，ショットピーニングを施したばねは, 使用環境の温度を考慮したうえで使用しなければならない ことを改めて確認することができた。

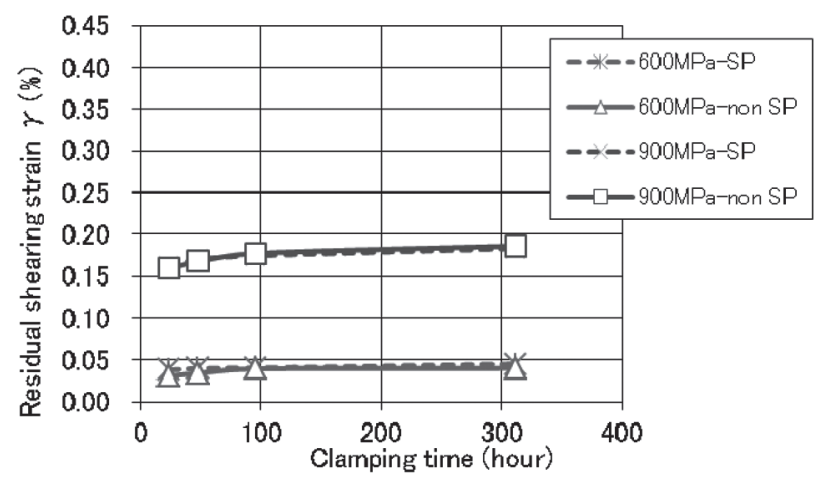

Fig. 3-18 (a) SWP-A[100 C ].

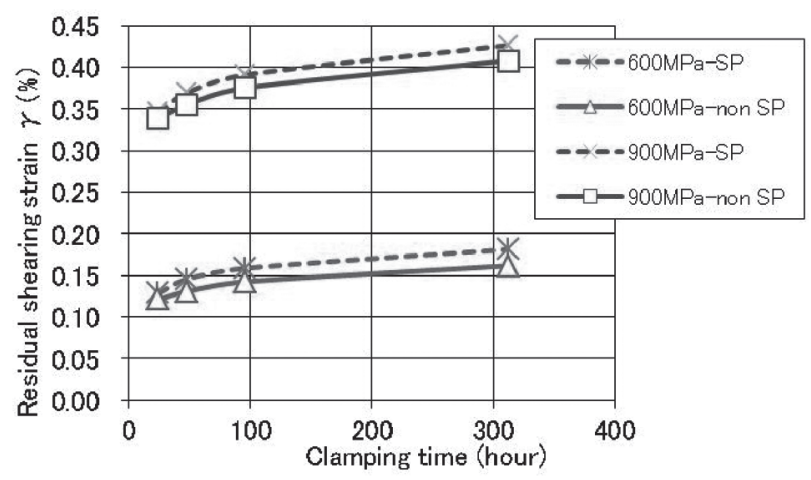

Fig. 3-18 (b) SWP-A $\left[200^{\circ} \mathrm{C}\right]$.

Fig. 3-18((a) (b)) Comparison of residual shear strain between non SP and SP springs. (SWP-A $\left[100,200^{\circ} \mathrm{C}\right]$ )

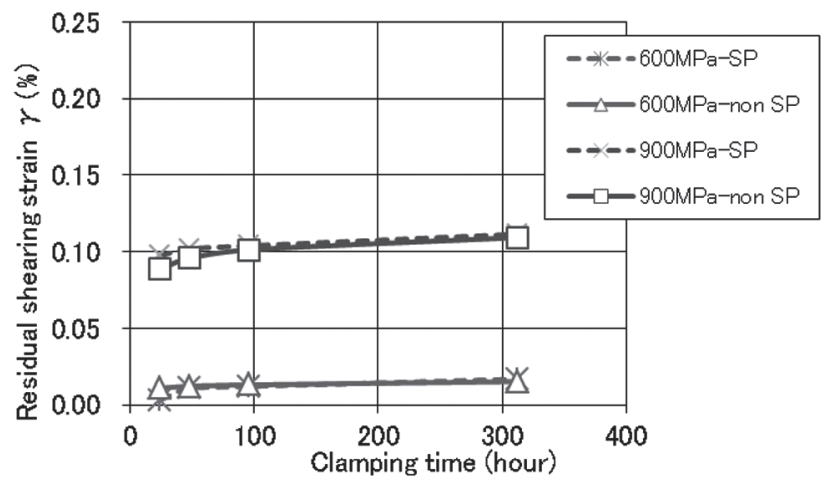

Fig. 3-19 (a) SWOSC-V $\left[100^{\circ} \mathrm{C}\right]$.

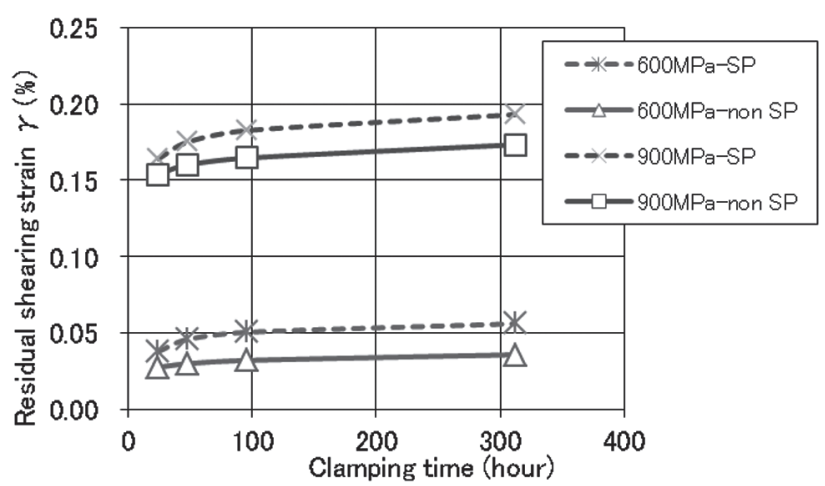

Fig. 3-19 (b) SWOSC-V $\left[200^{\circ} \mathrm{C}\right]$.

Fig. 3-19((a) (b)) Comparison of residual shear strain between non SP and SP springs. (SWOSC-V $\left[100,200^{\circ} \mathrm{C}\right]$ ) 


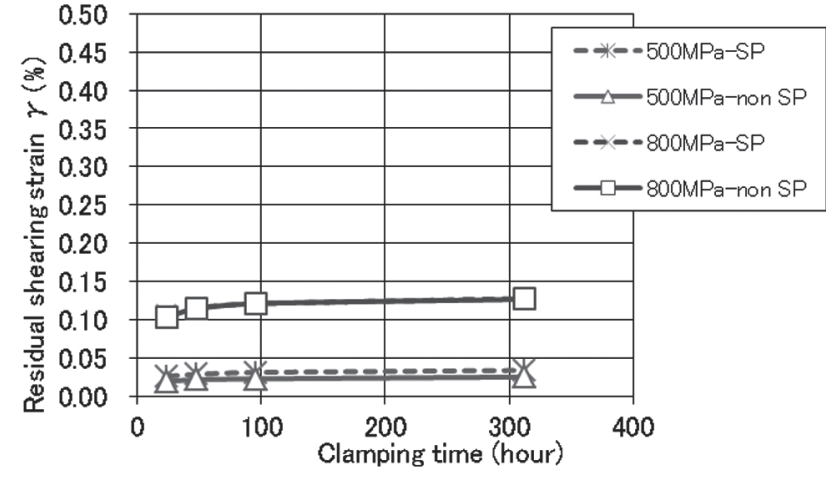

Fig. 3-20 (a) SUS304-WPB $\left[200^{\circ} \mathrm{C}\right]$.

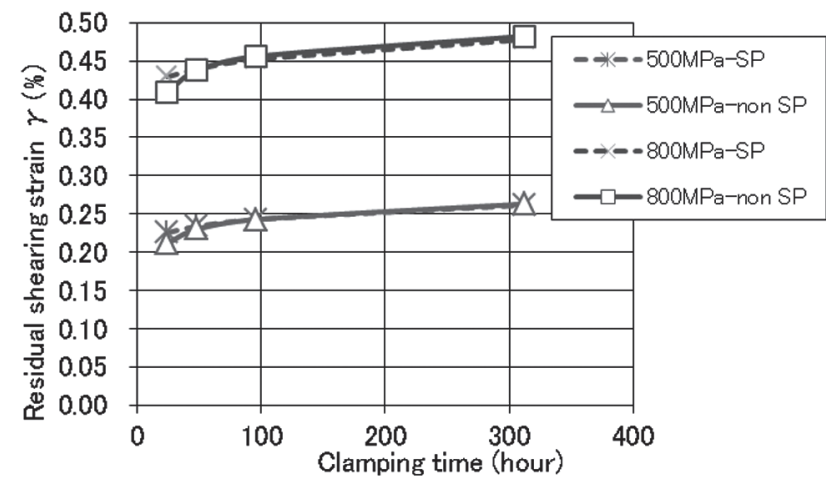

Fig. 3-20 (b) SUS304-WPB $\left[400^{\circ} \mathrm{C}\right]$.

Fig. 3-20((a) $\sim(b)) \quad$ Comparison of residual shear strain between non SP and SP springs. (SUS304-WPB $\left[200,400^{\circ} \mathrm{C}\right]$ )

\subsection{5 へたり量の予測計算式の検証}

SWOSC-V及びSUS304-WPBについて, 過去の研究委員 会 ${ }^{16)}$ にて提案された残留せん断ひずみ $\gamma$ の予測計算式を 用いた計算值と今回の実測值との整合性を検証した。 そ の結果, Fig. 3-21(a), (b) にSWOSC-Vでの検証デー夕を, Fig. 3-22 (a), (b) にSUS304-WPBでの検証デー夕を示すよう に, 低応力側では比較的良く一致したものの, 今回新たに 設定した高応力側での締付条件ではあまり一致しなかった。

なお，今回の試験デー夕を使用したへたり量の予測計算 式の検証，及び必要な見直しについては，現在まで十分に は行えていないため, SWP-Aについての予測式の検証と併 せて，さらに検討が必要で，今後の課題としたい．

\section{5 試験WGのまとめ}

(1)各線種(鋼種)の影響：締付温度が高く, 締付応力が高 いほど残留せん断ひずみ $\gamma$ は大きくなり，残留せん断ひ ずみ $\gamma$ は線径 $\phi 1.0 \mathrm{~mm}$ ではSWP-A $>$ SWOSC-V $>$ SUS304WPBであったが，線径 $\phi 4.0 \mathrm{~mm}$ ではSWP-A >SUS304WPB $>$ SWOSC-Vと逆転した。

○これはSWOSC-VとSUS304-WPBの硬さの差が, 線径 $\phi$ $1.0 \mathrm{~mm}$ に比べて $\phi 4.0 \mathrm{~mm}$ の方が大きいためで, 硬さが残 留せん断ひずみ とに影響することを実データでも確認で きた。

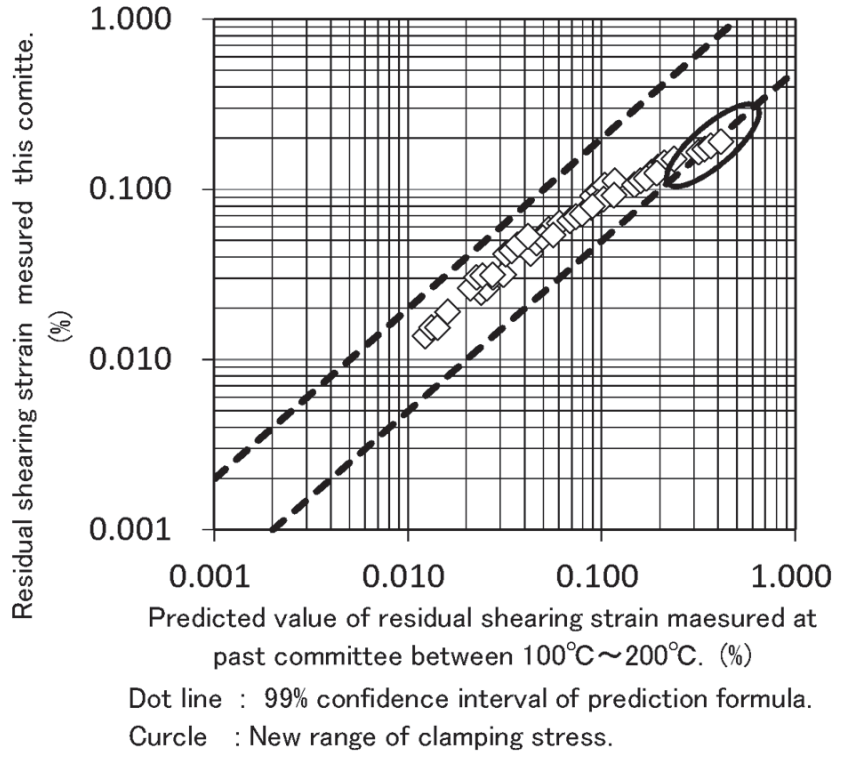

Fig. 3-21(a) Relationship between predicted value and measured value of residual shearing strain. (SWOSC-V $\phi 1.0 \mathrm{~mm}$ )

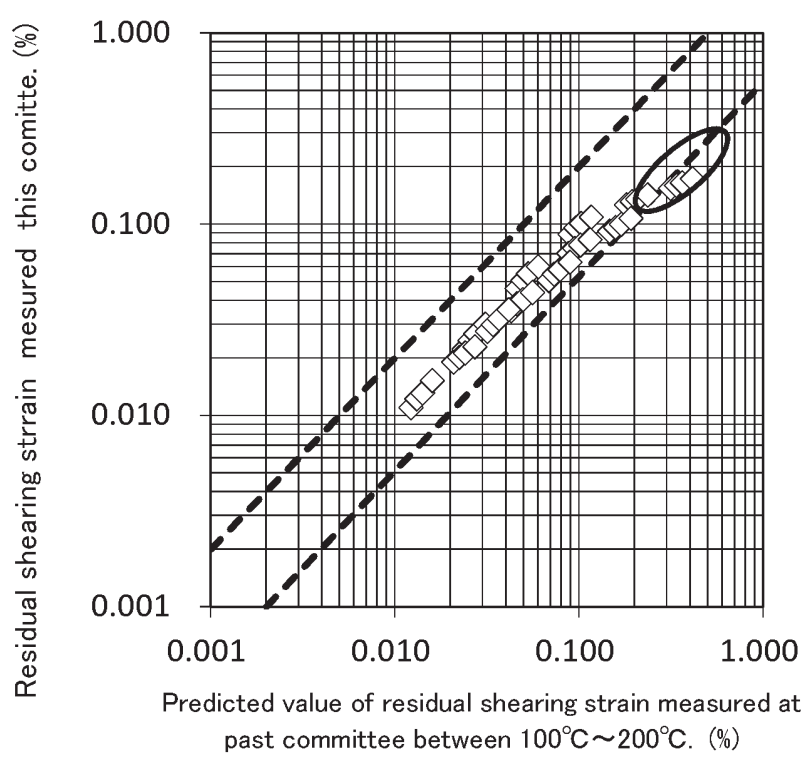

Dot line : $99 \%$ confidence interval of prediction formula

Curcle : New range of clamping stress.

Fig. 3-21 (b) Relationship between predicted value and measured value of residual shearing strain. (SWOSC-V $\phi 4.0 \mathrm{~mm}$ )

(2)線径による比較：SWP-A及びSWOSC-Vでは，残留せん 断ひずみ $\gamma$ が $\phi 1.0 \mathrm{~mm}>\phi 4.0 \mathrm{~mm}$ という関係を示したが, SUS304-WPBでは, 締付温度によって結果が異なり， (1) 項では，残留せん断ひずみ $\gamma$ が硬さに比例して変化する ことを示したが，ここでは反対の結果が得られ，硬さた けでは説明がつかないことがわかった。

○そこで，すでに報告されているセッチング効果を検証す 


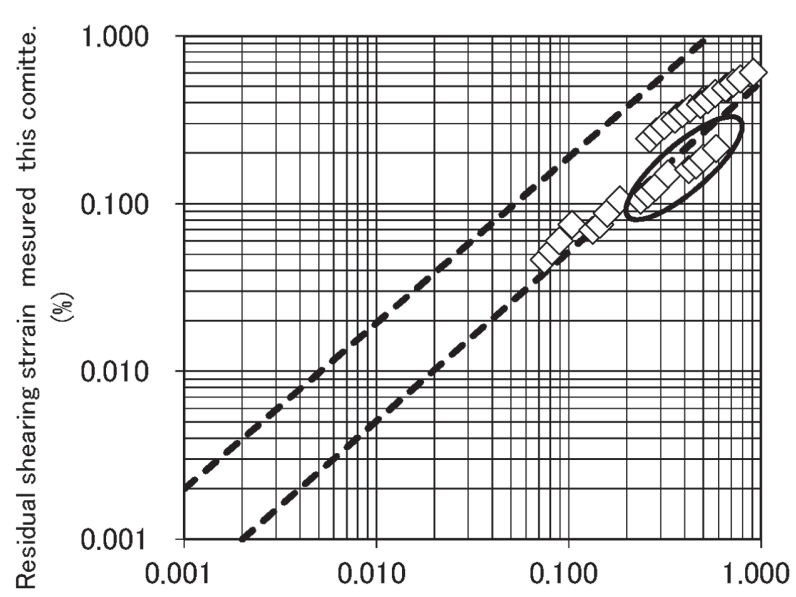

Predicted value of residual shearing strain measured at past committee between $300^{\circ} \mathrm{C} \sim 400^{\circ} \mathrm{C}$. (\%)

Dot line : $99 \%$ confidence interval of prediction formula. Curcle : New range of clamping stress.

Fig. 3-22(a) Relationship between predicted value and measured value of residual shearing strain. (SUS304-WPB $\phi 1.0 \mathrm{~mm}$ )

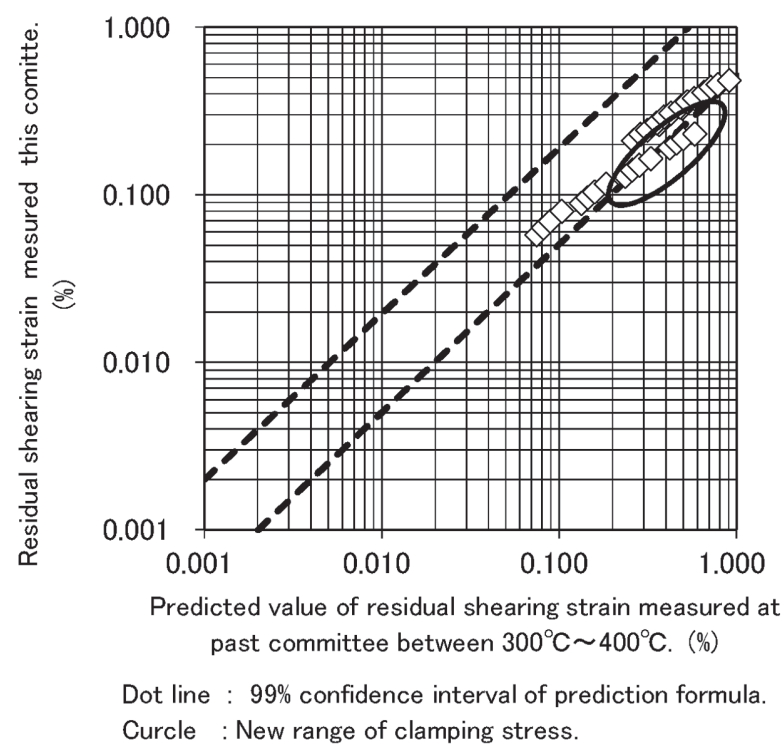

Fig. 3-22(b) Relationship between predicted value and measured value of residual shearing strain. (SUS304-WPB $\phi 4.0 \mathrm{~mm}$ )

る予定であったが, 今回の活動では比較検証が十分に行 えなかったため, 今後, S-S曲線の作成を含め試験検証 を追加する予定である。

(3)ショットピーニング有無の比較 : 各線種のばねについて 残留せん断ひずみ $\gamma$ に及ぼすショットピーニングの影響 を検証した結果, SWP-Aでは, 締付温度 $100^{\circ} \mathrm{C} て ゙ は$ 差は ないが, $200^{\circ} \mathrm{C}$ で残留せん断ひずみ $\gamma$ が増加したが, こ れはショットピーニングにより付与された残留応力が, 温間へたり試験中に，コイリング後の低温焼なまし処理
温度に近い条件で長時間保持されたことから減少してね じり降伏点が低下したためと考えられる-

OSWOSC-Vでは，ショットピーニングを施したばねの締付 温度 $200^{\circ} \mathrm{C}$ での残留せん断ひずみ $\gamma$ の増加量が大きく, こ れは付与された残留応力がSWOSC-Vのほうが大きいこと から可動転位量が多くなったためと考えられる.

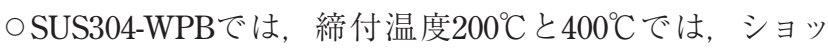
トピーニングによる差は現れなかったが, これは締付温 度が $400^{\circ} \mathrm{C}$ と高く，ショットピーニングにより付与した残 留応力が消失したため, 処理無しばねと同様の結果となっ たと考えられる。

○以上より，ショットピーニングを施したばねには，使用 環境の温度の考慮が必要なことを再認識した。

(4)へたり量 $\gamma$ の構成式(予測計算式)の検証 : SWOSC-V及び SUS304-WPBについて, 過去の委員会にて提案された残 留せん断ひずみ $\gamma$ の構成式を用いた計算值と今回の実測 值との整合性を検証した結果，低応力側では比較的良く 一致したものの, 今回新たに設定した高応力側での締付 条件ではあまり一致しなかった。

○今回の試験データを使用したへたり量の構成式の検証及 び必要な見直しは行えなかったため, SWP-Aの予測式の 検証と併せて, さらに検討が必要で, 今後の課題としたい.

\section{4. 結 言}

今回の活動の結果, 委員・関係者のご尽力により,「ばね メーカが小型コイルばねを設計・製作する時に，“温間へた り量 $(\gamma$ 值)”をある程度予測できるようなデータベースを作 成すること」はできたと考える。

すなわち，得られた温間へたりに関する諸データは，ば らつきが少なく，締付試験での負荷応力，温度，時間の影 響についても妥当な傾向が得られ, 過去の論文, 研究委員 会報告内容での傾向と一部の鋼種，温度域を除いて概ね一 致することも確認できた.

ただ，今回の活動の中では，S-S曲線を元にした温間へ たり量の検討・考察は行えず，また得られたデー夕を元に した予測計算式の高精度化にも至れなかったことをお詫び したい.

今後も必要と機会があれは，温間へたりに関するばね学 会研究委員会活動を継続いただき, 温度域によって異なる と推察される温間へたりのメカニズム検証と実用性の高い $\gamma$ 值予測計算式化を検討いただき，より有用な温間へたり に関する技術指針を提供いただけることを期待したい.

なお，今回の委員構成は主に中堅若手主体となり，各位 が文献収集と分類整理，温間へたり試験実施とデー夕整理 を積極的に実施し，2017年6月14日の中間報告会でも発表を 担当するなど熱心に活動下さったこと, 及び岡本副委員長, 荻原副委員長が各WG活動を積極的に進めて下さり，特に 岡本副委員長は力不足の委員長・川部を引張って中間報告 会、ばね論文集への投稿を主管下さったことを付記して感 謝の意を表したい. 
参考文献 (内容明示のため「文献題目」も記載)

(○内数字は, Table 2-2 ～2-4掲載の文献番号)

1 ）研究委員会報告（山田凱朗委員長）：ばね論文集「圧 縮コイルばねの疲労限度線図に関する共同研究」, 60, (2015), 53.

2 ) (1)長安 剛：ばね論文集「冷間成形コイルばねの高温締 付試験（報告1）」, No.9，(1963）， 78.

3) (2)岩田 斉, 荒川大次郎，里見祥明：ばね論文集「耐 熱ばね鋼について $\mathrm{Si}-\mathrm{Cr}$ 鋼の熱間及び疲労特性」, No.10, (1964), 12.

4 ) (3)中川 昭, 井上和政, 鈴木昭弘: ばね論文集「クロム・ シリコン鋼オイルテンパー線の性能について」, No.10, (1964), 16.

5 ) (4)分科会報告（富田勝信委員長）：ばね論文集「ばね用 ステンレス鋼線共同実験報告」，No.11，（1966），91.

6 ） (5)中川 昭, 井上和政，小泉義明，菅野憲興：ばね論文 集「 $\mathrm{Si}-\mathrm{Cr}$ 鋼, $\mathrm{Cr}-\mathrm{V}$ 鋼オイルテンパー線によるコイルばね の高温へタリについて」, No.12, (1967), 45.

7 ) (6)吉川文岳, 出口武：ばね論文集「Si-Cr鋼オイルテ ンパー線ばねの低温浸炭窒化による性能向上」, No.12 (1967), 36

8 ）(7)研究委員会報告（大野 明委員長）：ばね論文集「自 動車用弁ばねの耐久性能に関する研究」, No.13, (1967), 1.

9 ）8研究報告（大野明委員長）：ばね論文集「ばね用ス テンレス鋼線共同研究」, No.14, (1969), 75.

10）(9研究報告（大野 明委員長）：ばね論文集「ばね用ス テンレス鋼線共同研究報告（その2)」, No.17, (1972) 33.

11）(10荒川次郎, 上林三郎, 西田 彰, 藤田照夫, 佐藤和良： ばね論文集「ばね用耐孔食ステンレス鋼線について（第 1報)」, No.20，（1975）， 6 .

12）苜同研究報告（渡辺信一委員長）：ばね論文集「高強 度鋼線の疲れ強さに関する研究」，No.25，(1980)， 53.

13）(12)小泉義明，林 博昭，下田秀明：ばね論文集「各 種高強度ばね用ステンレス鋼線の比較試験」,No.28, (1983), 23

14）(13)谷本好則：ばね論文集「高強度細径ばね用ステンレス 鋼線」, No.29, (1984), 48.

15）(14)斎藤純幸, 芦野正美, 高橋健治：ばね論文集「コイ ルばねの高温へたりに及ぼすばね指数の影響」, No.32, (1987), 24.

16）(15)共同研究報告(田中千秋委員長):ばね論文集「SWOSC-V 及びSUS304-WPB耐熱ばねの長時間へたり特性」, No.34, (1989), 59.

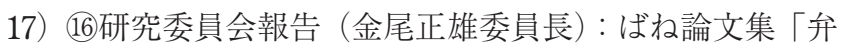
ばね用高強度Si-Cr鋼オイルテンパー線の研究」, No.40, (1995), 57.

18）研究委員会報告（木村雄二委員長）：ばね論文集「ス テンレス鋼線の耐久性に関する研究」No.46, (2001), 41.

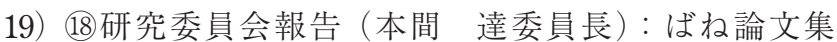

「コイルばねの形状と特性に及ぼす焼鈍条件」No.58, (2013), 49

20）共同研究報告（神原広司委員長）：ばね論文集「熱間 成形コイルばねのへたり試験法に関する研究」, No.30, (1985), 150.

21）研究委員会報告（新谷紀雄委員長）：ばね論文集「圧縮 コイルばねのへたりに関する研究」，No.59，（2014），47.

22）ばね技術研究会編，“ばね（第3版），(1982），439，丸善.

23）日本ばね工業会，“ばねハンドブック”，(2005），145，日 本ばね工業会.

Table 補足-1 温間へたりに関する18文献（1/3）

\begin{tabular}{|c|c|c|c|c|}
\hline No & 論文 & タイトル & 対象鋼種 & 結言（抜粋） \\
\hline (1) & $\begin{array}{l}\text { No.9 } \\
(1963)\end{array}$ & $\begin{array}{l}\text { 冷間成形コイルばねの高温締付試 } \\
\text { 験（報告1） }\end{array}$ & $\begin{array}{l}\text { SWP-A } \\
\text { SWOC-V } \\
\text { SWOC-VV }\end{array}$ & $\begin{array}{l}\text { 対象鋼種においては、、SWOC-VWが } \\
\text { 最も優れた鋼種の一つである。 }\end{array}$ \\
\hline (2) & $\begin{array}{l}\text { No.10 } \\
(1964)\end{array}$ & $\begin{array}{l}\text { 耐熱ばねね鋼にこつてSi-Cr鋼の熱間 } \\
\text { 及ひ疲労特性 }\end{array}$ & $\begin{array}{l}\text { SWOSC-V } \\
\text { SWOCV-V }\end{array}$ & $\begin{array}{l}\text { SWOSC-Vは、耐熱ばねとして、引 } \\
\text { 張、へたりり、疲労特性がSWOCV-V } \\
\text { より優れている。 }\end{array}$ \\
\hline (3) & $\begin{array}{l}\text { No.10 } \\
(1964)\end{array}$ & $\begin{array}{l}\text { クロム・シリコン鋼オイルテン } \\
\text { パー線の性能について }\end{array}$ & $\begin{array}{l}\text { SWOSC-V } \\
\text { SWOCV-V }\end{array}$ & $\begin{array}{l}\text { SWOSC-VはSWOCV-Vより耐熱性に } \\
\text { 優れ、耐へたり性も優昰である。 }\end{array}$ \\
\hline (4) & $\begin{array}{l}\text { No.11 } \\
(1966)\end{array}$ & $\begin{array}{l}\text { ばね用ステンレス鋼線共同実験報 } \\
\text { 告 }\end{array}$ & SUS27他 & $\begin{array}{l}\text { 締付試験において、応力、時間 } \\
\text { よりも温度の影響が大きく作用 } \\
\text { する。 }\end{array}$ \\
\hline (5) & $\begin{array}{l}\text { No.12 } \\
(1967)\end{array}$ & $\begin{array}{l}\mathrm{Si}-\mathrm{Cr} \text { 鋼, } \mathrm{Cr}-\mathrm{V} \text { 鋼オイルテンパー線 } \\
\text { によるコイルば高温ヘタリに } \\
\text { ついて }\end{array}$ & $\begin{array}{l}\text { SWOSC-V } \\
\text { SWOCV-V }\end{array}$ & $\begin{array}{l}\text { ヘたりりは比較的初期段階で現れ、 } \\
\text { 鋼種、ははね処理によってへた } \\
\text { り量は変化する。 }\end{array}$ \\
\hline (6) & $\begin{array}{l}\text { No.12 } \\
(1967)\end{array}$ & $\begin{array}{l}\text { Si-Cr 鋼オイルテンパー線ばねの低 } \\
\text { 温浸灰窒化による性能向上 }\end{array}$ & SWOSC-V & $\begin{array}{l}\text { 静的，動的，耐熱試験ともに, } \\
\text { 低温浸厔窒化したものは、へた } \\
\text { りが非常に小さい。 }\end{array}$ \\
\hline
\end{tabular}

Table 補足-2 温間へたりに関する18文献 $(2 / 3)$

\begin{tabular}{|c|c|c|c|c|}
\hline No & 論文 & タイトル & 対象鋼種 & 結言 (抜粋) \\
\hline (7) & $\begin{array}{l}\text { No.13 } \\
(1967)\end{array}$ & $\begin{array}{l}\text { 自動車用弁ばねの耐久性能に関す } \\
\text { る共同研究特集 }\end{array}$ & $\begin{array}{l}\text { SWP-V } \\
\text { SWO-V } \\
\text { SWOSC-V }\end{array}$ & $\begin{array}{l}\text { 変形限度は高温弾性限と一定関 } \\
\text { 係はなく, 鋼種による影響が } \\
\text { きい。 }\end{array}$ \\
\hline (8) & $\begin{array}{l}\text { No.14 } \\
\text { (1969) }\end{array}$ & ばね用ステンレス鋼線共同研究 & SUS27WH-C & $\begin{array}{l}\text { 静的，動的耐熱特性は，SWO-SC } \\
\text { にくらべ同等ない若干優れて } \\
\text { いる。 }\end{array}$ \\
\hline (9) & $\begin{array}{l}\text { No.17 } \\
(1972)\end{array}$ & $\begin{array}{l}\text { ばね用ステンレス鋼線共同研究報 } \\
\text { 告 (その2) }\end{array}$ & $\begin{array}{l}\text { SUS27WH-B } \\
\text { SUS27WH-C }\end{array}$ & 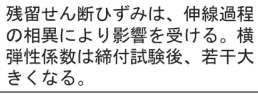 \\
\hline (10) & $\begin{array}{l}\text { No.20 } \\
\text { (1975) }\end{array}$ & $\begin{array}{l}\text { ばね用耐孔食ステンレス鋼線につ } \\
\text { いて (第1報) }\end{array}$ & $\begin{array}{l}\text { SUS316 } \\
\text { SUS304 } \\
\text { SUS304+Mo }\end{array}$ & $\begin{array}{l}\text { SUS304に IMoを添加すると、耐へ } \\
\text { たり性能は向上する。 }\end{array}$ \\
\hline (11) & $\begin{array}{l}\text { No.25 } \\
\text { (1980) }\end{array}$ & $\begin{array}{l}\text { 高強度鋼線の疲れ強さに関する研 } \\
\text { 员 }\end{array}$ & $\begin{array}{l}\text { SWC } \\
\text { SWPP-A } \\
\text { SWO-V,他 }\end{array}$ & $\begin{array}{l}\text { 炭素鋼系の高強度鋼線の耐へた } \\
\text { り性は、高強度にししても効果は } \\
\text { 期待できない。 }\end{array}$ \\
\hline (12) & $\begin{array}{l}\text { No.28 } \\
(1983)\end{array}$ & $\begin{array}{l}\text { 各種高玧度ばね用ステンレス鋼線 } \\
\text { の比較試験 }\end{array}$ & $\begin{array}{l}\text { SUS304-WPB } \\
\text { SUS631-WPC }\end{array}$ & $\begin{array}{l}\text { ヘたり性 : オーステナイト系> } \\
\text { サブゼロ加工系>析出硬化系 }\end{array}$ \\
\hline
\end{tabular}

Table 補足-3＼cjkstart温間へたりに関する18文献（3/3）

\begin{tabular}{|c|c|c|c|c|}
\hline No & 論文 & タイトル & 対象鋼種 & 結言（抜粋） \\
\hline (13) & $\begin{array}{l}\text { No. } 29 \\
(1984)\end{array}$ & 高強度細径ばね用ステンレス鋼線 & $\begin{array}{l}\text { SUS304-WPB } \\
\text { SWP-B }\end{array}$ & $\begin{array}{l}\text { 供試材の高温におけるる゙ねなの残 } \\
\text { 留せん湅種間の差が } \\
\text { 著しい。 }\end{array}$ \\
\hline (14) & $\begin{array}{l}\text { No. } 32 \\
(1987)\end{array}$ & $\begin{array}{l}\text { コイルばねの高温へたりに及ぼす } \\
\text { ばね指数の影響 }\end{array}$ & $\begin{array}{l}\text { SWP-A } \\
\text { SWOSC-V } \\
\text { SUS304-WPB }\end{array}$ & 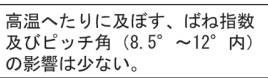 \\
\hline (15) & $\begin{array}{l}\text { No.34 } \\
(1989)\end{array}$ & $\begin{array}{l}\text { SWOSC-V及びSUS304-WPB耐熱ばねの } \\
\text { 長時間へたり特性 }\end{array}$ & $\begin{array}{l}\text { SWOSC-V } \\
\text { SUS304-WPB }\end{array}$ & $\begin{array}{l}\text { 解析時、係数の温度依存性があ } \\
\text { る温度を境にしして異なっていた。 } \\
\text { 今後の検討課題。 }\end{array}$ \\
\hline (16) & $\begin{array}{l}\text { No.40 } \\
(1995)\end{array}$ & $\begin{array}{l}\text { 弁ばね用高玧度Si-Cr鋼オイルテン } \\
\text { パー線の研究 }\end{array}$ & $\begin{array}{l}\text { SWOSC-V } \\
\text { 高強度 } \\
\text { SWOSC-V }\end{array}$ & $\begin{array}{l}\text { 材料を高強度化すると、耐へた } \\
\text { り性は低下した。（－部条件を } \\
\text { 除く） }\end{array}$ \\
\hline (17) & $\begin{array}{l}\text { No.46 } \\
(2001)\end{array}$ & $\begin{array}{l}\text { ステンレス鋼線の柇久性に関する } \\
\text { 研究員会報告 }\end{array}$ & $\begin{array}{l}\text { SUS302 } \\
\text { SUS304 }\end{array}$ & $\begin{array}{l}300,400^{\circ} \mathrm{C} \text { 高温へたりり性は高引 } \\
\text { 張強さほどへたやすい。(但し } \\
\text { 理由は不明) }\end{array}$ \\
\hline (18) & $\begin{array}{l}\text { No. } 58 \\
(2013)\end{array}$ & $\begin{array}{l}\text { コイルばねの形状と特性に及ぼす } \\
\text { 焼鈍条件 }\end{array}$ & $\begin{array}{l}\text { SWP-B } \\
\text { SWOSC-V } \\
\text { SUS304-WPB }\end{array}$ & $\begin{array}{l}\text { SWOSC-V: } 360 \sim 420^{\circ} \mathrm{C} \\
\text { SUS304-WPB: } 350 \sim 450^{\circ} \mathrm{C} \\
\text { の低温焼鈍により、へたり少と } \\
\text { なる。 }\end{array}$ \\
\hline
\end{tabular}

※活動当初に文献WGが調査対象とした728文献のリスト は，ばね学会HPに掲載予定である。 